ГОЦЕ НАУМОВ

UDC: 903.4(497.774/.775)"63/653"

Центар за истражување на предисторијата

Универзитет „Гоце Делчев“, Штип

gocenaumov@gmail.com

\title{
ПЕЛАГОНСКИТЕ ТУМБИ ОД ПРЕДИСТОРИЈАТА ДО СРЕДНИОТ ВЕК
}

\begin{abstract}
Ancтракт. - Од предисторијата до денес Пелагонија, претставува една од најплодните житници во Македонија, поради што разни популации биле привлечени да се населат во овој регион. На тој начин се формирале бројни предисториски, антички, средновековни и модерни населби кои се развиле во културни центри во своето време. Оваа традиција започнала во неолитот, кога пред 8000 години првите земјоделски заедници ги населиле плодните пелагонски полиња и го иницирале процесот на доместикација, како на житариците и животните, така и на сопствената општествена улога. Првите земјоделци ги формирале своите села на мали природни возвишенија кои со континуираното живеење добиле карактер на тумби. Лоцирани близу до нивите и мочуриштата, тумбите биле безбедно место за повеќе генерации да езгистираат во благосостојба, која пак овозможила процут во доменот на културата, економијата и верувањата.
\end{abstract}

Меѓутоа, во последните фази на предисторијата тумбите го губат својот населбински карактер за да повторно бидат користени како простор за основање на вили рустики во античкиот период. Тумбите го задржале својот стопански карактер, повторно насочен кон земјоделството, меѓутоа тие повеќе не функционирале како села туку добиле улога на архитектонски комплекс кој овозможувал акумулирање на житото и негова дистрибуција во разни делови на Римската Империја. Слична функција тумбите имале и во средниот век со тоа што тие почнале да се користат и како некрополи каде што средновековните заедници ги погребувале своите блиски. Ваквата улога на тумбите од предисторијата до средниот век укажува на нивниот придонес во иницирање и развивање на низа социјални, економски и религиозни процеси кои значително се рефлектирале врз архитектурата, материјалната култура и обредите.

Во археолошката наука тумбите најчесто се проучувани и дискутирани во однос на нивните предисториски карактеристики. Ваквиот пристап е сосем очекуван со оглед на тоа што овие специфични археолошки локалитети се формирани во неолитот и неретко функционираат во енеолитот и бронзеното време. Меѓутоа, скоро воопшто не се говори за нивното функционирање во антиката и средниот век. Иако во овие периоди тумбите немаат таква истакната населбинска улога како во предисторијата, сепак тие имаат зна- 
чителен придонес во економскиот и обредниот живот на античките и средновековните популации. Во времето на доцната антика овие вештачки формации се користат за градење на стопански објекти (вила рустика) и бројни јами околу нив за депонирање на жито. Оваа функција тие ја задржуваат и во средниот век, со тоа што добиваат и сакрален карактер, па се користат и како некрополи на населението што живее во околните села.

Во оваа пригода ќе се образложат географските, социјалните и симболичките мотиви за нивно формирање во неолитот на Пелагонија, како и нивниот континуитет во антиката и средниот век, после 5 милениуми отсуство од било каква активност во рамки на нивната површина. Овој мошне долг период на нивно не ангажирање, како и потребата за повторно вклучување на тумбите во социјалниот и обредниот живот на античките и средновековните популации, го истакнува нивниот специфичен карактер и потенцијалот за нивно вклучување во низа економски и симболични процеси. Поради тоа, ќе се направи увид во начинот на нивно формирање и функционирање во неолитот, за да потоа преку конкретни примери од неколку локалитети во Пелагонија се претстави и нивната улога во антиката и средниот век.

Тумбите се општествен феномен што се појавува во неолитот на Блискиот Исток и потоа преку Мала Азија и Балканскиот Полуостров се шири сѐ до Централна Европа. Овие вештачки формирани ридчиња се суштински поврзани со почетокот на земјоделството и континуираниот живот во определена населба на една заедница (сл. 1). Тоа се темели на лесниот пристап до прехрамбени ресурси и можноста за нивно долготрајно акумулирање. Ваквите економски придобивки ќе предизвикаат општествени промени кои ќе ги формираат првите земјоделски заедници, и кои со помали или поголеми локални модификации, ќе останат стабилни неколку стотици или илјадници години. Освен ефектот врз стопанството, овие промени ќе влијаат и врз идеологијата на првите земјоделци, што пак евидентно ќе се манифестира во материјалната култура.

Поради својот комплексен карактер и општествена динамика, тумбите се проучувани од повеќе стручњаци. Тие се составен дел од студиите за формациските процеси на населбите, природните услови во кои тие се создаваат, демографската динамика, архитектонските технологии, населбинските стратегии, економските карактеристики на населението, нивните занаетчиски достигнувања и идеологијата која играла клучна улога во формирањето и континуитетот на овие специфични локалитети. ${ }^{1}$ Како резултат на овие обемни

${ }^{1}$ Perlès, Catherine. The Distribution of Magoules in Eastern Thessaly. In Halstead, P. (ed.) Neolithic Society in Greece (1999), 42-56. Sheffield: Sheffield Academic Press; Kotsakis, Kostas. What Tells Can Tell: Social Space and Settlement in the Greek Neolithic. In Halstead, P. (ed.) Neolithic Society in Greece (1999), 66-76. Sheffield: Sheffield Academic Press; Bailey, Douglas. What is a Tell? Settlement in fifth millennium Bulgaria. 
истражувања, понудени се мноштво на одговори и толкувања што мошне темелно ги објаснуваат тумбите и оние што нив ги создавале и користеле за живеење. Секако, ваквите сознанија не може да се аплицираат генерално за сите тумби од Блискиот Исток до Анадолија бидејќи повеќе од очигледно е дека бројни се причините кои доведуваат до локални варијации на овој населбински феномен.

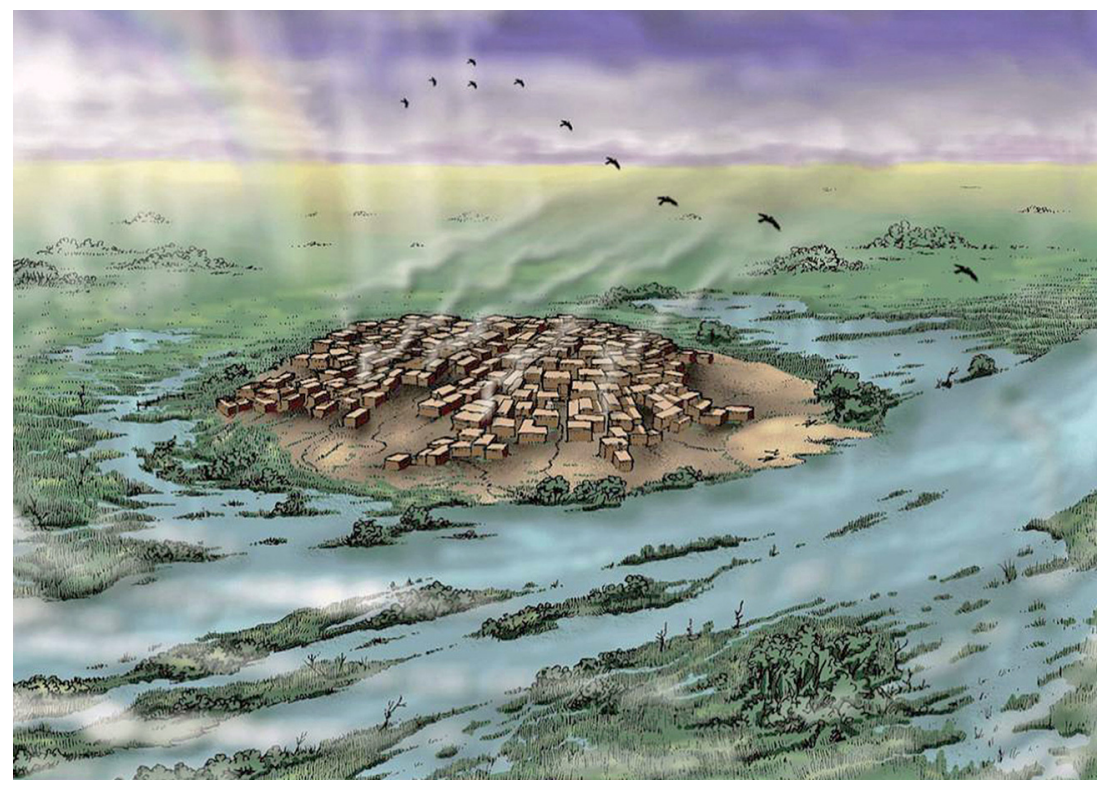

сл. 1. Реконструкција на локалитетот Чаталхујук, една од најголемите тумби во Анадолија, Турција (илустрација на Џон Свогер).

Сепак, присутни се и одредени појави карактеристични за тумбите во Анадолија, а кои можат да се следат до Балканот и особено во Пелагонија. На формирањето на тумбите во Балканот му претходи процес кој се развивал во Анадолија и со демографските промени и миграциите во раниот неолит се транспонира во Тесалија. Познати се бројни тумби во овоие региони кои укажуваат на брзото формирање населби и користењето на голем дел од котлината за земјоделски активности. ${ }^{2}$ Секако, овој феномен е регистриран и во Бугарија, Македонија, Романија, делумно во Албанија и Србија, но скоро целосно отсуствува во Црна Гора, Хрватска и Словенија. Тоа пока-

In Brück, J. and Goodman, M. (eds.) Making places in the prehistoric world: themes in settlement archaeology (2002), 94-111. Cambridge: University of Cambridge; Rosenstock, Eva. Tells in Südwestasien und Süosteuropa: Verbreitung, Entstehung und Definition eines Siedlungsphänomens. Urgeschichtliche Studien II: Grunbach, 2009; Hofmann, R.; Moetz, F. K. and Müller, J. Tells: Social and Environmental Space. Bonn: Rudolf Habelt GMBH, 2012; Naumov, G. 'Tell communities and wetlands in the Neolithic Pelagonia, Republic of Macedonia'. Documenta Praehistorica 43 (2016), 327-342.

${ }^{2}$ Perlès 1999; Rosenstock 2006. 
жува дека земјоделците што ги формирале овие населби повеќе преферирале рамници отколку ридско-планински региони, така што го имале предвид и присуството на мочуришта во близина на нивните населби. Тоа се темели на економските мотиви за формирањето на земјоделските села во котлините, односно на брзиот пристап до плодна почва во која можеле да ги одгледуваат житариците, но и полесно да ја носат стоката на пасење и поење. Близината на мочуриштата формирани од изливањето на реките или малите езера, имала значителен економски ефект и обезбедувала поголем простор со плодна почва за култивирање на житарици, но исто така придонесувала и за поквалитетно одгледување на добитокот. Ваквите природни и економски фактори секако се одразиле и врз социјалната структура во рамки на населбите, што имало свои рефлексии во архитектурата и репрезентативните предмети.

\section{Неолитските тумби во Македонија и Пелагонија}

Феноменот на неолитски тумби се појавува во повеќе делови на Македонија, и тоа не многу подоцна отколку неговата манифестација во Тесалија. Имено при крајот на 7-от милениум п.н.е. се започнало со градење на првите неолитски населби во Македонија, меѓу кои биле и оние во форма на тумби (сл. 2). Како и во случајот со анадолските и тесалските тумби, и тие се формираат во рамниците близу до мочуриштата, а како такви може особено да се истакнат скопскиот, полошкиот, овчеполскиот и пелагонскиот регион. Тоа потврдува дека и во овие региони, во периодот на холоценот се развиле услови за започнување со земјоделство и населување на поголеми популации кои со себе носеле домашни животни, грнчарија, алатки и градежни техники, претходно непознати во времето на палеолитот и мезолитот. И тука првите населби се основале во близина на мочурливите предели и континуирано се користеле, при што постепено го добиле обликот на тумби.

Таков е случајот со Катлановското Езеро во Скопската Котлина (пресушено во втората половина на 20-от век), а во чија близина се наоѓаат неолитските тумби кај Маџари, Чаир, Стајковци, Арачиново, Мршевци и други. ${ }^{3}$ Со текот на времето овие езера ја менувале својата површина поради што се менувал и распоредот на тумбите околу нив. Меѓу нив особено се истакнува тумбата кај скопската населба Маџари, која е истражувана повеќе од останатите во овој регион. Резултатите посочуваат на комплексна населба со густо распоредени правоаголни куќи од лепеж, импресивна материјална

${ }^{3}$ Санев, Воислав. „Неолитско светилиште од Тумба во Маџари“. Macedonia Acta Archaeologica 9 (1988), 9-30. Скопје; Tolevski, Igor and Stančevski, Ivan Katlanovsko ezero-Blato i negovata okolina: kulturni impulsi od neolitskiot period. Vo Fidanoski, Lj. and Naumov, G. (ur.) Neolitot vo Makedonija II: čekor napred vo proučuvanjeto na prvite zemjodelski opštestva (2018), 43-56. Skopje: Centar za istražuvanje na predistorijata. 
култура сочинета од сликани садови, детално изработени антропоморфни модели на куќи, жртвеници и фигурини, како и погребување на новороденчињата во и до живеалиштата. ${ }^{4}$

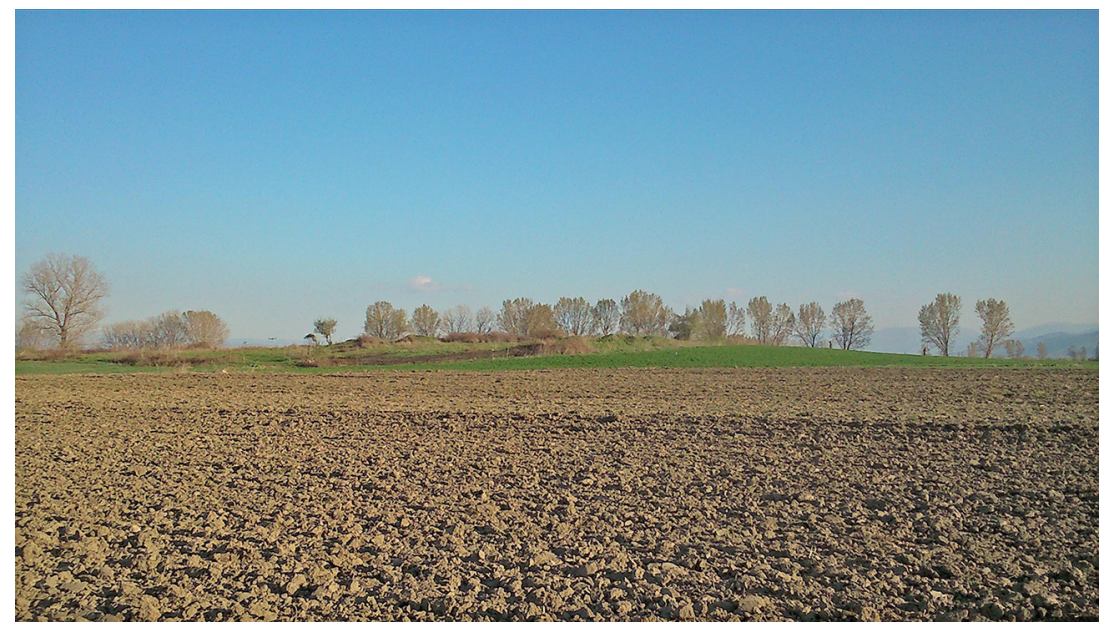

сл. 2. Локалитетот Велушка Тумба во Пелагонија (фотографија Гоце Наумов).

Во полошкиот регион бројот на откриени тумби е далеку помал и меѓу нив познати се оние во близина на селата Стенче, Долно Палчиште и Брвеница. ${ }^{5}$ Тие по својот населбински карактер се слични на оние од Скопската Котлина, со исклучок на тоа што некои од нив се активни и подоцна во предисторијата. Што се однесува до Овче Поле, тумбите не се истакнати како вообичаена појава, но локалитетот кај Амзабегово се дефинира како таков после неговото истражување од поголем меѓународен тим. ${ }^{6}$ Иако оваа населба е формирана на возвишение над овчеполската рамница, сепак во литературата се претставува како тумба, и тоа во близина на плодни полиња во времето на неолитот. За разлика од наведените региони во кои бројот на тумби е релативно мал, Пелагонија се истакнува како котлина во која досега е откриен најголемиот број на

${ }^{4}$ Санев 1988; Стојанова Канзурова, Елена. Архитектонски недвижни објекти од Тумба-Маџари. Macedoniae Acta Archaeologica 20 (2011), 35-52. Скопје.

5 Здравковски, Драгиша. „Неолитска населба „Под село-Тумба“ с. Стенче“. Зборник на Музејот на Македонија 2 (археологија) (2005), 25-31. Скопје; Здравковски, Драгиша и Саржоски, Саржо. „Тумба Палчиште, неолитска, енеолитска и бронзенодобна населба“. Arheološki Pregled 28 (1989), 43. Ljubljana. Абази, Љуљета и Толевски, Игор. Стратиграфска слика за локалитетот Тумба-Брвеница. Во Наумов, Г. и Фиданоски, Љ. (ур.) Неолитот во Македонија: во чест на Воислав Санев (2019), 11-34. Скопје: Центар за истражување на предисторијата.

${ }^{6}$ Gimbutas, Maria. Anza, Neolithic Macedonia, As reflected by Excavation at Anza, Southeast Yugoslavia, 1976. Los Angeles: The Regents of the University of California; Санев, Воислав. Амзабегово: населба од раниот, средниот и доиниот неолит во Македонија, Штип: НУЗСК-Штип, 2009. 


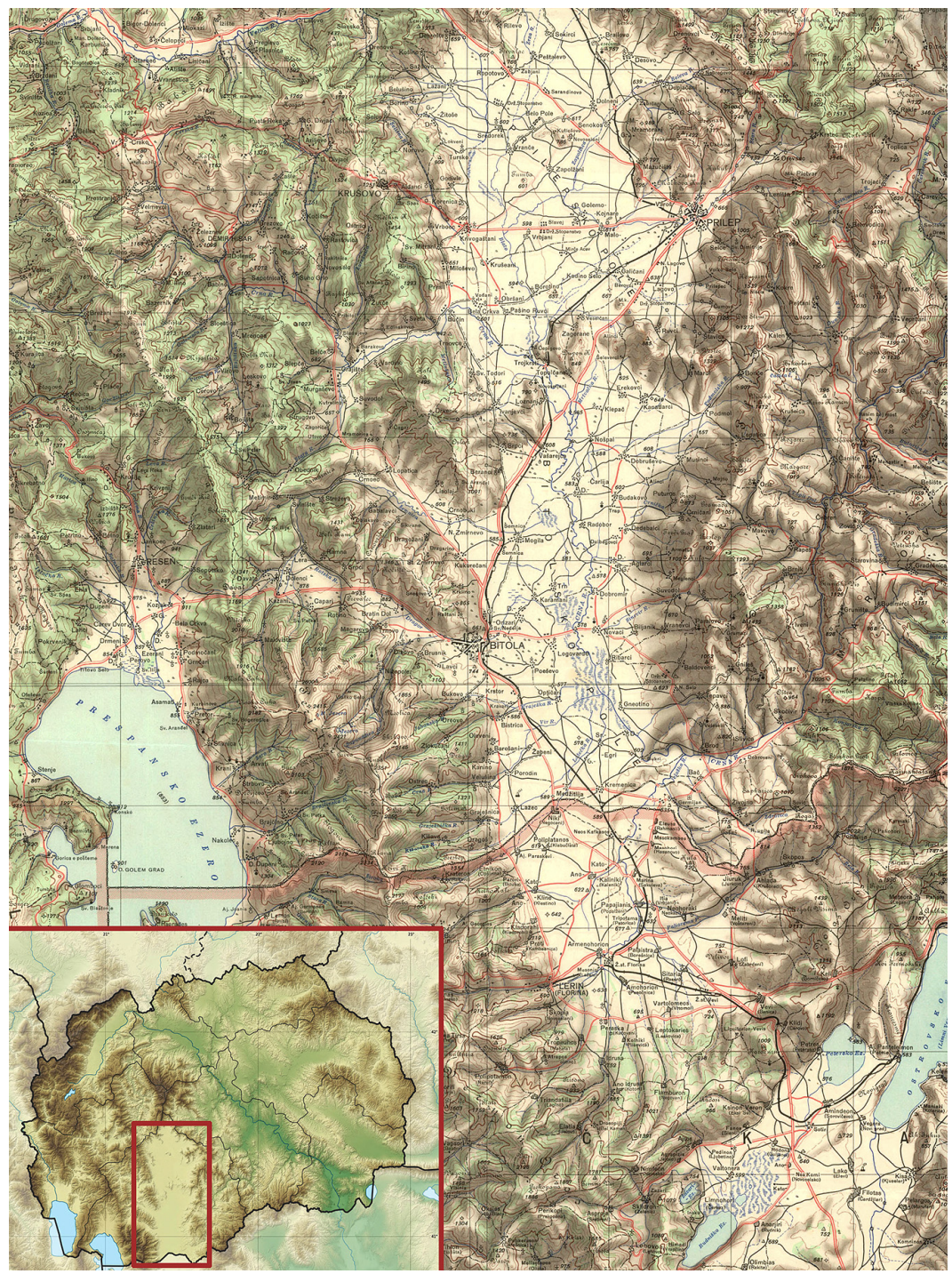

сл. 3. Карта на Пелагонија со нејзината позиција во рамки на Македонија.

вакви населби и воопшто на неолитски локалитети во Македонија. Нивниот број приближно изнесува 160, што пак укажува на привлечноста за нејзино населување од страна на првите земјоделци. ${ }^{7}$ Пелагонија претставува издолжена котлина опколена со планините Баба, Бушева, Селечка, Даутица, Бабуна, Ниџе и Нередска, а низ која тече реката Црна со неколку помали притоки (сл. 3).

${ }^{7}$ Симоска, Драгица и Санев, Воислав. Праисторија во Централна Пелагонија, Битола: Народен музеј Битола, 1976; Naumov 2016. 
Благодарение на ваквата географска структура во неогенот, во Пелагонија имало езеро кое во текот на плиоценот, преку реките Црна и Вардар, се излеало во Егејското Море. ${ }^{8}$ Тоа довело до формирање на алувијална почва која подоцна во неолитот ќе има клучна улога во формирањето на првите земјоделски заедници во оваа котлина. Во прилог на ваквите погодни географски обележја оди и честото излевање на реката Црна и понирањето на подземните води, потпомогнато од топењето на снегот од околните високи планини. На тој начин се формирале сезонски масивни мочуришта кои овозможувале поплавување на почвата и подобрување на нејзиниот агрономски квалитет. Освен тоа мочуриштата биле извор на бројни ресурси, како што се рибите, птиците, жабите, змиите, трската и калта, неопходни за исхраната и архитектурата на првите земјоделски заедници во Пелагонија.

Битната улога на мочуриштата во неолитска Пелагонија се потврдува со самиот распоред на тумбите во нивната близина. Во рамките на т.н. Битолско Поле, кое се наоѓа во централниот дел на Пелагонија, се откриени најголемиот број на тумби и повеќето од нив се лоцирани околу некогашните мочуришта што се пресушени со мелиорациските процеси во 1960 -те години. ${ }^{9}$ Иако се неопходни дополнителни геоархеолошки истражувања за овој регион, ваквиот распоред на тумбите укажува на тоа дека во неолитот постоеле мочуришта во чија близина се основале тумби. Од друга страна, геолошките истражувања во т.н. Прилепско Поле, кое се наоѓa во северниот дел на Пелагонија, потврдуваат постоење на мочуриште во чија близина исто така се наоѓаaт повеќе тумби. ${ }^{10}$ Тоа покажува дека сегашниот пејсаж во одредена мера се разликува од предисторискиот, но благодарение на најновите истражувања во кои се земаат предвид геолошките, археоботаничките и ГИС анализите, може да се има некаков увид во неолитската природна околина.

Оттука сосема е јасно е дека поводот за рапидно населување на Пелагонија во неолитот е плодната почва во близина на мочу-

${ }^{8}$ Dumurdzanov, Nikola; Serafimovski, Todor and Burchfiel, Clark, B. Evolution of Neogene-Pleistocene Basins of Macedonia. Digital Map and Chart Series 1 Acompanying notes). (Boulder: Geological Society of America), 2004; Наумов, Гоце; Миткоски, Александар; Талевски, Христијан; Александар Мургоски; Никола Думурџанов, Јаромир Бенеш, Ивана Живаљевиќ, Југослав Пендиќ, Дарко Стојаноски, Хуан Хибаха, Николо Маsуко, Алберт Хафнер, Сонке Зидат, Весна Димитриевиќ, Софија Стефановиќ, Кристина Будилова, Михаела Вихронова, Тереза Мајеровичова и Јиржи Бумерл, Истражување на локалитетот Врбјанска Чука во 2017 година. Balcanoslavica 47 (1) (2018), 253-285.

${ }^{9}$ Наумов, Гоце и Стојкоски, Слободан. „Нови предисториски тумби во Пелагонија“. Зборник на трудови на Завод и музеј-Битола 18 (2015), 169-183. Битола; Симоска и Санев 1976; Naumov 2016.

${ }^{10}$ Гоце Наумов, Александар Миткоски, Александар Мургоски и Ѓоре Милевски, Рекогносцирање на предисториски локалитети во Северна Пелагонија, Патримониум 15 (2017), 11-36. Скопје. 
риштата. Треба да се истакне дека мезолитски населби сѐ уште не се евидентирани во оваа котлина, иако постојат одредени скромни сознанија за палеолитски алатки. ${ }^{11}$ Секако, со оглед на рекогносцирањата поврзани со пораните предисториски периоди, не може да се негира можното постоење на мезолитски локалитети во котлината или падините, меѓутоа повеќе од очигледно е дека наглото населување во овој регион се случило во неолитот, и тоа особено во неговите порани фази (сл. 3). Тоа го потврдуваат археолошките ископувања и рекогносцирањата на тумбите кај Породин, Оптичари, Егри, Добромири, Кравари, Гургур, Трн, Могила, Карамани, Тополчани, Пашино Рувци, Славеј, Врбјани и други. ${ }^{12}$ На одредени локации, не ретко има и повеќе тумби една до друга (од 2 до 6), што покажува дека тие места биле особено атрактивни и овозможувале стабилна земјоделска економија.

Што се однесува до хронолошките рамки на овие тумби, треба да се истакне дека дел од нив се основани околу 6000 година п.н.е., односно меѓу 6200 и 5800 година п.н.е. ${ }^{13}$ Од оваа група на дати отстапува онаа од Тополчани, која може да се смести во средината на 7-от милениум п.н.е., но нејзината веродојстоност е дискутабилна. За разлика од Тополчани, датите од Врбјанска Чука, Велушка Тумба, Тумба Породин, Тумба Средсело и Тумба Оптичари, се базирани на повеќе примероци и може да се сметаат за поверодостојни. Тие хронолошки се движат во наведениот временски распон од неколку века околу 6000 година п.н.е., што може и условно да се земе како период на масовно населување на Пелагонија од страна на првите земјоделски заедници. Освен ранонеолитските дати, хронолошките анализи на тумбите во Пелагонија потврдуваат и локалитети што што биле активни во средината и втората половина на 6-от милениум п.н.е., целиот петти милениум п.н.е., како и околу 2 000-та година п.н.е., а кои се однесуваат на локалитетите кај Могила, Породин, Маркови Кули, Трн, Црнобуки и Карамани. ${ }^{14}$ Тоа значи дека тумби се формирале и при крајот на неолитот, но и во енеолитот и бронзеното време, на тој начин истакнувајќи го овој мочурлив простор како атрактивен и во доцните етапи на предисторијата, со исклучок на железното време кое воопшто не е констатирано на овој вид населби.

Ваквата хронолошка распространетост е секако евидентна и во материјалната култура која покажува очигледни типолошки обележја карактеристични за раниот неолит, енеолитот и бронзеното

${ }^{11}$ Кузман, Паско. „Палеолит во Македонија“. Macedonia Acta Archaeologica 13 (1993), 13-18. Скопје.

${ }^{12}$ Симоска и Санев, 1976; Наумов и Стојковски, 2015; Наумов и др. 2017.

${ }_{13}$ Наумов, Гоце. Калибрирана хронологија на неолитските тумби во Македонија. Во Наумов, Г., и Фиданоски, Љ. (ур.) Неолитот во Македонија: нови сознанија и перспективи (2016), 67-96. Скопје: Центар за истражување на предисторијата.

${ }^{14}$ Наумов 2016. 
време. Што се однесува до архитектурата, до неодамна се сметаше дека тумбите во Пелагонија имаат униформен карактер, односно дека во нив се содржани неолитски села со слична просторна организација. Меѓутоа во последните неколку години на десетина тумби се интензивираше геомагнетното скенирање што даде сосем нови сознанија за внатрешниот распоред на градбите и воопшто за изгледот на самите неолитски и енеолитски села. Резултатите од овие истражувања покажуваат дека не се сите тумби слично организирани. Имено, некои од нив се опкружени со ров, други имаат линиски или концентричен распоред на градби, а кај неколку скоро воопшто не се познаваат градби поради отсуството од горење на живеалиштата што всушност ги дава и магнетните сигнали при овој вид истражувања. ${ }^{15}$ Ова покажува дека социјалната структура во неолитските населби не била идентична, што довело и до различно организирање на населбинскиот простор (сл. 4).
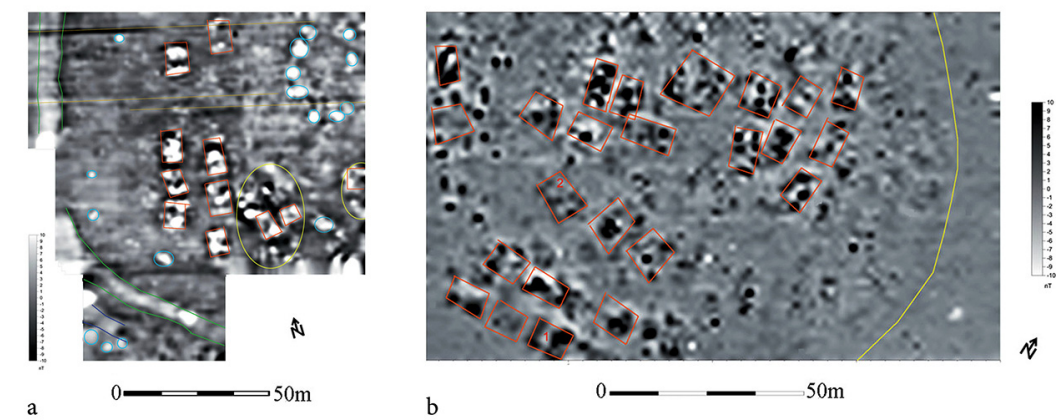

сл. 4. Резултати од геомагнетно скенирање на тумбите кај Добромири и Трн (Наумов и др. 2014, сл. 14).

И покрај тоа што се смета дека тумбите се засноваат на идеолошка предлошка, која во преден план ги става врските со предците и градењето живеалишта врз нивните градби, ${ }^{16}$ сепак овој симболичко-социјален принцип бил натамошно развиван и варирал во однос на внатрешните општествени состојби во секоја населба за-

${ }^{15}$ Наумов, Гоце, Тержиецки, Марчин, Пшибила, Марчин, Чвиеј, Малгоржата, Бугај, Урсула, Шчепаник, Пјотр и Подсјадло, Марта. „Археолошко, топографско и геофизичко истражување на неолитски тумби во Пелагонија“. Патримониум 12 (2014), 345-372. Скопје; Наумов, Гоце; Миткоски, Александар; Мургоски, Александар; Бенеш, Јаромир; Милевски, Горе; Пшибила, Марчин; Комаркова, Вероника; Вихронова, Михаела и Стоимановски, Ивица. „Истражување на Врбјанска Чука кај Славеј-2016“. Патримониум 14 (2016), 13-42. Скопје; Naumov, Goce, Jan John and Ondrej Chvojka. Geophysical scanning of prehistoric tells in Central Pelagonia. In Fidanoski, Lj. and Naumov, G. (eds.) Neolithic in Macedonia II: step forward in the study of the first farming societies (2017), 161-180. Skopje; Наумов и др. 2018;

${ }^{16}$ Kotskakis, 1999. 
себно. Тоа делумно се рефлектира и во архитектурата и материјалната култура регистрирани на пелагонските тумби. Иако неолитската архитектура содржи бројни сличности, сепак не секаде постојат исти градежни карактеристики. Сознанијата за градбите во тумбите се мали, но може да се констатира дека прво нивната сочуваност е различна, а потоа и внатрешната организација. Остатоците од градби во тумбите кај Могила, Оптичари, Добромири, Гургур и Тополчани се едвај регистрирани, ${ }^{17}$ што е повеќе резултат на архитектонските техники отколку на карактерот на земјата во која тие се распаѓале. Освен парчињата лепеж, не се констатирани зидови или структури од овој материјал. Очигледно тие не биле подложни на силен оган кој би довел до повцрста структура на лепежот од кого биле градени. Оваа практика на случајно или намерно палење на неолитските куќи, особено карактеристична за Балканот, не може да се потврди и на овие локалитети.

За разлика од нив, на тумбите кај Породин, Радобор и Славеј, регистрирани се повеќе градби со јасно оформени зидови и внатрешни инсталации од глина. ${ }^{18}$ Тоа е секако резултат на горењето на зидовите, за кои не може да се докаже дали биле палени намерно или случајно. Но тоа довело до мошне добро сочувани масивни Sидови во чија структура лесно се распознаваат градежните обележја, односно примената на дрвени столбови, колци и прачки. Но од друга страна, без разлика на присуството на пожари, инсталациите од глина биле цврсти и компактни, поради што и добро се сочувале. Во некои од градбите има и повеќе вакви структури за обработка и чување житарици, односно подоготовка и печење на леб, што говори и за различната социјална структура на заедниците од овие населби, а за која подолу подетално ќе се говори. Во споредба со овие населби, на оние поврзани со горе наведените локалитети без сочувани зидови од градби, воопшто не се регистрирани вакви инсталации. Ваквата ситуација не се должи на тоа што овие градби не се палени, туку на општото отсуство на овој тип масивни инсталации за стопански активности. Тоа може и делумно да биде резултат на скромната истраженост на овие локалитети, но исто така и на тоа дека заедниците од овие неолитски села на поинаков начин го чувале и процесирале житото и печеле лебот.

Ваквите разлики во архитектурата се рефлектираат и во материјалната култура на пелагонските земјоделски заедници. Пелаго-

17 Симоска, Драгица; Китаноски, Благоја и Тодоровиќ, Јован. „Неолитска населба во село Могила кај Битола“. Macedonia Acta Archaeologica 5 (1979), 9-30; Симоска, Драгица и Кузман, Паско. „Тумба Оптичари“. Arheološki Pregled 1988 (1990), 63-66. Ljubljana; Китаноски, Благоја, Симоска, Драгица, и Тодоровић, Јован. Нови археолошки истражувања на населбата Чука во Тополчани кај Прилеп. Macedonia Acta Archaeologica 4 (1978), 9-32. Прилеп; Наумов и др. 2017.

18 Симоска, Драгица и Санев, Воислав. „Неолитска населба Велушка тумба кај Битола“. Macedoniae Acta Archaeologica 1 (1975), 25-85; Китаноски, Благоја. „Врбјанска Чука“. Arheološki pregled 1987: (1989), 47-48. Ljubljana. 
нија традиционално се третира како култура целина во рамки на Велушко-породинската група, пред сѐ поради сличните обележја во типологијата и декорацијата на садовите, антропоморфните модели на куќи, жртвениците, фигурините итн. Сепак, и покрај унифицираниот карактер и импресивноста на овие артефакти, може да се забележат и различни локални пристапи при изработката на овие предмети или пак преовладување на одредени наоди на некои локалитети што се ретки, односно отсутни на други. Тоа особено се забележува во домен на садовите и моделите на куќи. Во централниот дел на Пелагонија доминираат садови со бела декорација и модели со истакнати антропоморфни и архитектонски елементи, додека во северниот дел тие се редуцирани и почесто се сликаат црни бледи орнаменти. Но во секој случај, на локалитетите во целата котлина импонираат велелепните садови, керамичките модели, жртвениците и фигурините, кои говорат за општествените и уметничките достигнувања на првите земјоделци во овој регион.

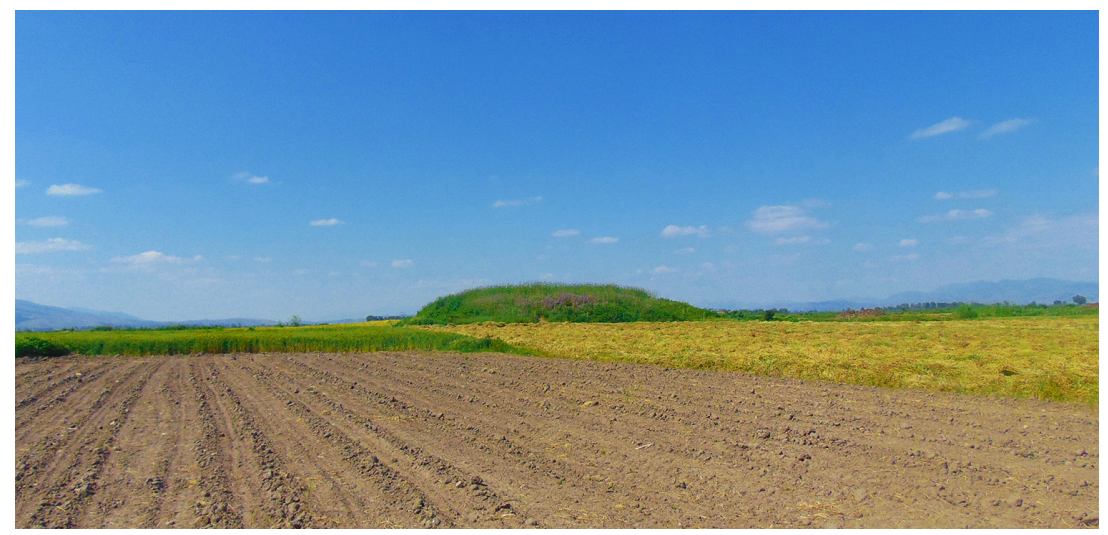

сл. 5. Локалитетот Тумба кај Карамани (фотографија Гоце Наумов).

Од една страна, овие регионални обележја укажуваат на тоа дека заедниците во Пелагонија имале истакнат идентитет кој, освен во релација со регионот на Охридското Езеро, не бил изедначен со оние што живееле северно и источно од оваа котлина. ${ }^{19}$ И покрај тоа што во рамки на Амзабегово-вршничката културна група, карактеристична за горната половина на Македонија, во првата половина на шестиот милениум п.н.е. се случуваат значителни промени во материјалната култура, сепак елементите на визуелниот идентитет во Пелагонија не се менуваат. Белото сликање на керамиката, формите на садовите, моделите на куќи со антропоморфни цилиндри и голем дел од останатите артефакти остануваат непроменети сѐ

19 Naumov, Goce. Formation of Wetland Identities in the Neolithic Balkans. In Shydlovskyi, P. (ed.) Prehistoric Networks in Southern and Eastern Europe. Vita Antiqua Series 10 (2018), 48-60. Kiev: Taras Shevchenko University. 
до доцниот неолит кога во рамки на Трнската културна група значително ќе се смени изгледот на повеќето предмети, а некои од овие категории и целосно ќе ги снема.

Таков е случајот со антропоморфните модели на куќи и масичките со архитектонски обележја, кои скоро воопшто не се произведуваат во пелагонскиот доцен неолит. Овие артефакти се особено карактеристични за раниот неолит во оваа котлина, кога заедниците ја фокусираат нивната идеологија на куќите со тоа што масивно произведуваат модели кои ги прикажуваат нивните живеалишта или други видови на стопански, односно ритуални објекти. ${ }^{20}$ Антропоморфните еквиваленти на оваа категорија предмети ја истакнуваат силната врска меѓу одредени индивидуи и објекти така што тие се идентификуваат во рамки на симболичко хибридно поврзување на човечкото тело со градбите. На тој начин веројатно се истакнувала битната улога на одредени членови на заедницата, па затоа и овие предмети се користеле како комеморативни светилки. Во домен на ваквото изедначување на индивидуи со куќите може да се посочи и практикувањето на погребување на починати под или во близина на градбите во многу неолитски локалитети на Балканот. $^{21}$ Меѓутоа, ваквата пракса воопшто не е присутна на тумбите во Пелагонија, каде што до сега не е регистрирано ниту едно неолитско погребување. За разлика од неолитот, овие тумби во средниот век често се користат како некрополи на населението што живеело во нивна близина.

\section{Тумбите од доцната предисторија до средниот век}

Како што беше и погоре наведено, некои неолитски тумби продолжуваат да функционираат како населби во енеолитот и бронзеното време, додека други згаснуваат во неолитот и повторно се активни дури после повеќе од 5000 години, односно во антиката и средниот век. Континуитетот на тумбите во енеолитот и бронзеното време не изненадува бидејќи тие сѐ уште се користат како населби и не ја менуваат значително својата улога во домен на стопанските

${ }^{20}$ Naumov, Goce. Housing the Dead: Burials inside houses and vessels from Neolithic Balkans. In Malone, C. and Barrowclough, D. (eds.), Cult in Context: Reconsidering Ritual in Archaeology (2007), 255-265. Oxford: Oxbow Books; Naumov, Goce Patterns and Corporeality: Neolithic Visual Culture from the Republic of Macedonia. Oxford: British Archaeological Reports-International Series, 2009; Chausidis, Nikos. Neolithic Ceramic Figurines in the Shape of a Woman-House from the Republic of Macedonia. In Gheorghiu, D. and Cyphers, A. (eds.), Anthropomorphic and Zoomorphic miniature figures in Eurasia, Africa and Meso-America: morphology, materiality, technology, function and context (2010), 25-35. Oxford: Archaeopress.

${ }^{21}$ Бъчваров, Крум. Неолитни погребални обреди. София: Бард, 2003; Naumov, Goce. Embodied houses: social and symbolic agency of Neolithic architecture in the Republic of Macedonia. In Hoffman, D. and Smyth, J. (eds.) Tracking the Neolithic house in Europe-sedentism, architecture and practice (2013), 65-94. New York: Springer. 
приоритети, односно земјоделството како примарна гранка. Тоа го потврдуваат локалитетите кај селата Карамани, Радобор, Могила, Меџитлија, Канино, Трн, Новаци, Кравари, Логоварди, Црнобуки, Врбјани, Боротино, Коњари, Кадино и Пашино Рувци. ${ }^{22}$ Меѓутоа после овие етапи на предисторијата има целосно згаснување на животот на тумбите и тие не се користат во следните неколку илјада години и покрај нивната одлична местолоположба (сл. 5).

Останува нејасно која е причината за отсуство на населби на тумбите во железното време и раната антика, но може да се претпостави дека општествените приоритети се фокусирани на освојувањето и заштитата на ресурси, така што и утврдувањата се градени далеку од рамниците, односно од пелагонските полиња. Но сепак, во доцната антика и средниот век оваа состојба се менува, па тумбите повторно стануваат интересни во домен на земјоделството. Овој пат тие не се користат како основа за населбински простор, туку на нив се градат стопански објекти и се вкопуваат јами за чување на жито (силоси). На некои од тумбите се основала вила рустика, градба во која се живеело меѓутоа со примарна улога како центар на економскиот посед (латифундиум), во кого се вршело орање, сеење и жнеење на нивите, како и чување на домашни животни. ${ }^{23}$ Иако поради парцијалните истражувања на тумбите не постојат доволно информации, сепак се смета дека имало само еден ваков објект во кого се чувало житото и градинарските култури.

Антички архитектонски и градежни елементи се откриени на повеќе пелагонски тумби, како што се оние кај Славеј, Кукуречани, Мусинци, Ношпал и Трап. ${ }^{24}$ Иако на повеќето од овие локалитети не се вршени ископувања, може да се очекува постоење на вили рустики. Со оглед на малите димензии на тумбите, овие објекти биле изолирана појава, односно не биле дел од населби. И покрај тоа што во овие градби постоеле компартименти во кои најверојатно се депонирало житото, сепак во нивна близина, односно на врвот на тумбите, се копале и длабоки јами со истата намена. Тоа овозможувало депонирање на поголема количина на жито, веднаш после неговото жнеење во околните полиња, како и заштита од дождови и ветар, но исто така и од животни и птици.

Ваквите јами се користеле и во средниот век, односно се копале и нови, и тоа во многу поголем број. Тоа го потврдуваат иско-

22 Симоска и Санев, 1976; Симоска и др. 1979; Наумов и др. 2017; Симоска, Драгица; Китаноски, Благоја и Тодоровиќ, Јован. „Населбата Црнобуки и проблемот на истоимената култура во светлината на новите археолошки истражувања“. Macedonia Acta Archaeologica 2 (1976), 43-83. Прилеп; Миткоски, Александар „Нови сознанија за енеолитот во прилепскиот дел на Пелагонија и Мариово“, Зборник на трудови 20 (2017), Битола; Темелкоски, Душко. „Енеолитска населба Крушеанска Чука“. Macedonia Acta Archaeologica 15 (1999) 33-45.

${ }^{23}$ Наумов и др. 2018.

${ }^{24}$ Коцо, Димче и Грозданов Цветан. Археолошка карта на Република Македонија. Скопје: Македонска академија на науките и уметностите, 1996. 
пувањата на тумбите кај Оптичари, Могила, Тополчани, Славеј и други, ${ }^{25}$ каде што се откриени јами длабоки и повеќе од два метра. Нивниот квантитет и големи димензии покажуваат дека во тумбите се депонирале големи количини на жито, а кое најверојатно се дистрибуирало во околните села или се мелело во брашно на самото место. На тоа посочуваат остатоците од градби, мелнички камења и црепни во кои се печел лебот, со што на некој начин тумбите имале функции како и античките вили рустики. Изгледот на овие објекти во средниот век бил доста поскромен во споредба со нивните антички еквиваленти, со оглед на малиот број на остатоци од градби и нивното тешко детектирање во археолошките слоеви.

Меѓутоа во средниот век, тумбите покрај тоа што имале стопанска улога, не ретко се користеле и како некрополи, односно како места во кои се погребувале луѓето од околните села. Ваквиот начин на нивно користење делумно изненадува доколку се има предвид дека на нив се депонирало жито и имало функционални објекти, но не и цркви. Прашањето е дали стопанските и ритуалните активности се одвивале во различни етапи, или пак како што некои истражувања покажуваат можеби и истовремено? Иако ваквата двојна улога на тумбите во средниот век отвора дилеми, сепак не треба да се занемарат и симболичките аспекти на овие вештачки форми, а кои се присутни уште во времето на нивното настанување во предисторијата. Имено, не случајно се избираат тумбите како места за погребување, бидејќи содржат неколку религиски и практични компоненти. Од една страна, положувањето на блиските на височинка овозможува нивно издвојување од останатиот свет, додека од друга, присуството на покојниците во простор кој се користи за чување на жито, на симболичко ниво обезбедува и нивно повторно раѓање, односно патување во вечноста (обреден чин некогаш проследен и со јадење на блага пченица).

При разгледување на ваквите религиски аспекти преку погребувањето на средновековното население на тумби, треба да се имаат предвид практичниот и социјалниот карактер на овој обред. Положувањето на покојниците на повисоко место не дозволува нивно оштетување од мочурливите и подземните води, а кои ги имало во изобилство во Пелагонија во поголемиот дел од годината. Исто така, погребувањето на членови на заедницата надвор од селото, односно далеку од селската црква, може да има и одредена социјална заднина доколку станува збор за припадници на понискиот сталеж, или пак се однесува на сосема поинаква група на население. Во прилог на тоа говори и отсуството на гробни прилози и накит во најголемиот број на откриени гробови при ископувањата, иако некои исклучоци (со накит типичен за западноевропското занаетчиство) говорат и за тоа дека станува збор за популации кои не потек-

${ }^{25}$ Симоска и Санев 1976; Симоска и др. 1979; Китаноски и др. 1978; Симоска и Кузман 1990; Наумов и др. 2018. 
нуваат од Балканот. ${ }^{26}$ Сепак, колку и да се скромни гробните форми, тие укажуваат на стандардните христијански фунерарни норми и положување на покојниците во правец исток - запад. Подоцна, во 19-от век, ваквото средновековно погребување на тумбите ќе се обнови, па во некои случаи дури и ќе се изградат цркви на овие места, каков што е примерот со тумбите кај Новаци, Кравари, Егри и други (сл. 6). ${ }^{27}$

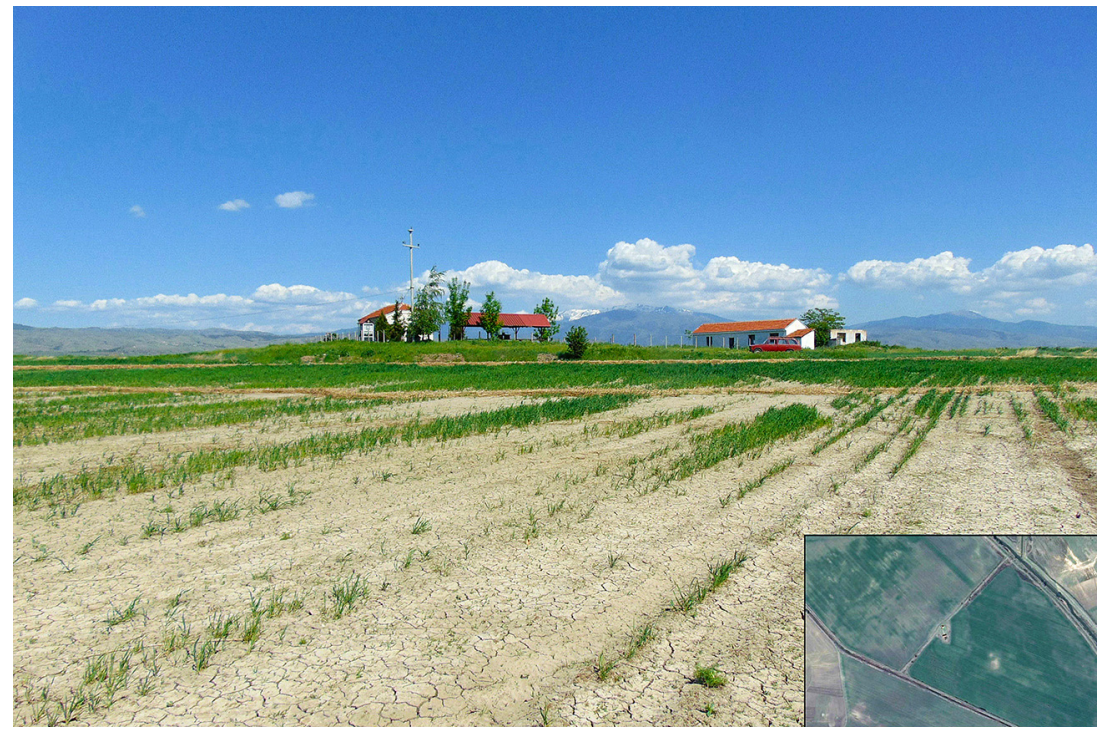

сл. 6. Локалитетот Св. Богородица кај Егри (фотографија Гоце Наумов).

\section{Врбјанска Чука во неолитот, антиката и средниот век}

Општиот преглед на пелагонските тумби нивните општествени, стопански и ритуални аспекти во предисторијата, антиката и средниот век дава солидни сознанија за начинот на кој овие специфични вештачки форми настанувале и натамошно се користеле. Меѓутоа, за да се разбере потемелно нивната функција во разни хронолошки етапи, неопходно е да се направи детален увид во една од тумбите и на тој начин да се види кои се нејзините обележја и како тие би можеле да се исползуваат за поаргументирано толкување на оние што живееле на нив или во нивна близина. Една од можеби најдобро истражените тумби во Пелагонија која дава темелни сознанија за првите земјоделски заедници во регионот е Врбјанска Чука (сл. 7). Локалитетот е откриен при крајот на 1970-те и ископуван е во следната декада, кога се добиени првични и битни сознанија за

\footnotetext{
${ }^{26}$ Симоска и др. 1979.

27 Симоска и Санев 1976; Наумов и Стојковски 2015.
} 
неолитската населба. ${ }^{28}$ Во последните пет години овој локалитет повторно се истражува со меѓународни тимови кои применуваат мултидисциплинарни методи, а со што се добива уште потемелен увид во оваа тумба и нејзината хронологија, архитектура, материјална култура, економија, општествена структура и обредите. ${ }^{29}$ Резултатите од истражувањата на Врбјанска Чука овозможуваат подобро да се разберат пелагонските општества во неолитот, антиката и средниот век, а коишто својата егзистенција, организација, технологија и идеологија ги базирале на земјоделството.

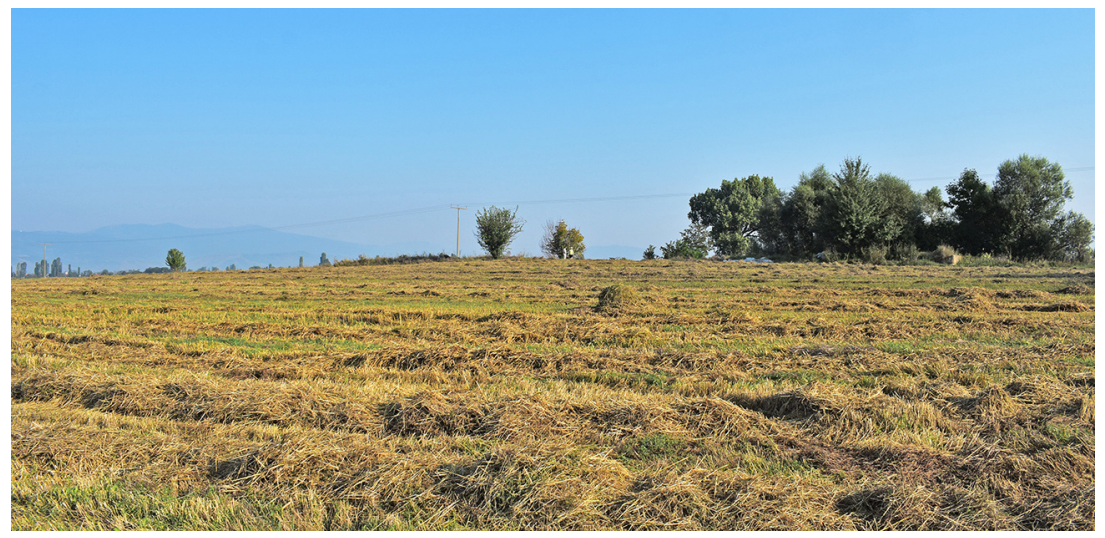

сл. 7. Локалитетот Врбјанска Чука кај Славеј (фотографија Гоце Наумов).

Врбјанска Чука се наоѓa во северниот дел на Пелагонија, во рамницата меѓу Селечка и Бушева Планина, односно во близина на селата Славеј и Врбјани (сл. 8). Таа е основана врз природно возвишение од песок, формирано од неогенско езеро чие истекување довело до создавање алувијална почва. Како денес, така и во неолитот, оваа плодна почва била предуслов за населување на заедници кои своето стопанство го концентрирале претежно на земјоделството. Во прилог на изборот на оваа локација е постоењето на мочурливо земјиште, неколку километри југо-источно од тумбата, што воедно ce совпаѓa со моделот на формирање тумби во повеќе региони на Балканот. $^{30}$ Освен реката Блато, денес не постојат други во близина на тумбата, меѓутоа во околината се забележуваат канали кои веројатно им припаѓале на притоки или поголеми потоци.

${ }_{28}^{28}$ Китаноски 1989; Миткоски, Александар. „Врбјанска Чука кај селото Славеј, Прилепско“. Зборник на Музеј на Македонија 2 (2005), 33-46. Скопје.

${ }^{29}$ Наумов и др. 2016; Наумов и др. 2018; Naumov i dr. 2018; Naumov, Goce, Mitkoski, Aleksandar, Talevski, Hristijan, Anvari, Jana, Przybila, Marcin, Stojanovski, Darko, Antolín, Ferran, Sabanov, Amalia, Živaljević, Ivana, Dimitrijević, Vesna, Gibaja, Juan, Mazzucco, Niccolo, Milevski, Gjore, Dumurđanov, Nikola, Pendić, Jugoslav, Blažeska, Zlata, Stefanović, Sofija. Early Neolithic tell of Vrbjanska Čuka in Pelagonia. Praehistorische Zeitschrift (in press).

${ }^{30}$ Наумов и др. 2018. 


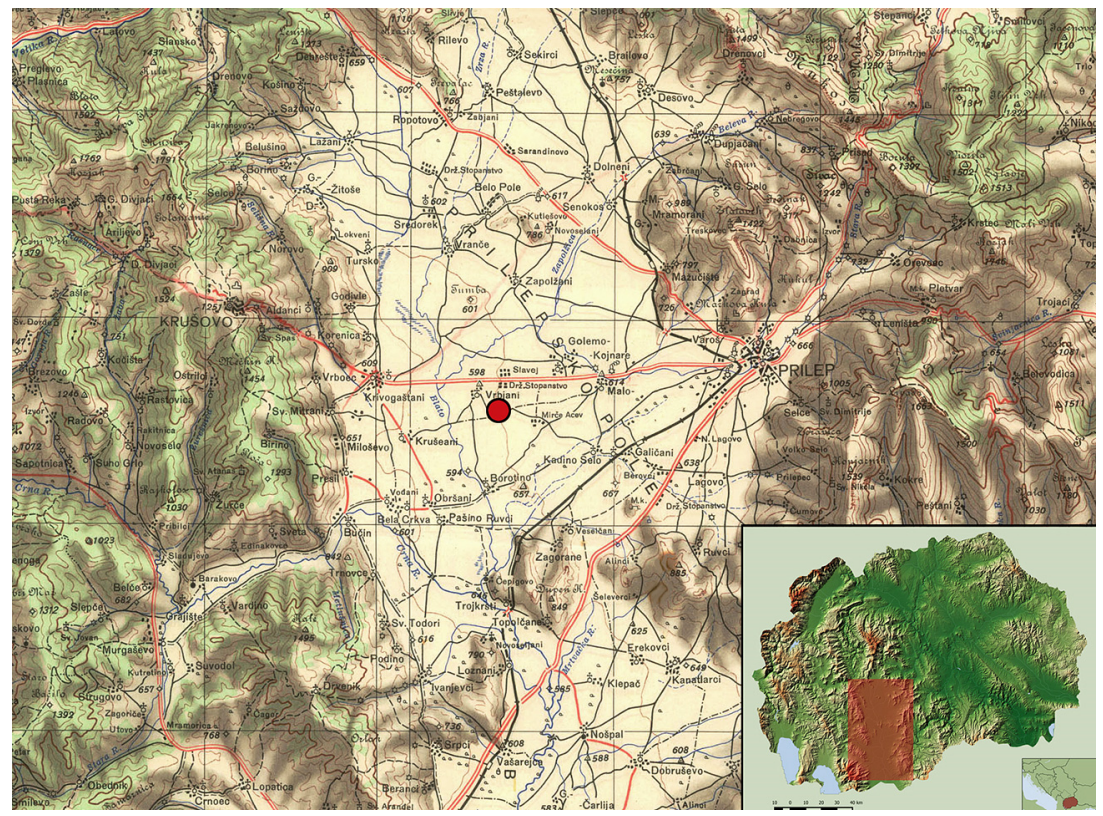

сл. 8. Карта на Пелагонија и позицијата на локалитетот Врбјанска Чука во северната половина на котлината.

Во 2016 и 2019 се изврши дигитална топографија на тумбата со што прецизно се утврди нејзината зафатнина и висина, ${ }^{31}$ иако и во 1980-те приложија првични информации за нејзините површински карактеристики. ${ }^{32}$ Според најновите мерења тумбата е висока 4 метри и нејзиниот дијаметар изнесува 130 метри, така што претставува еден од поголемите вакви локалитети во овој дел од Пелагонија. Сепак, нејзините димензии и висина се помали во однос на тумбите регистрирани во Тесалија и Анадолија, што делумно се темели и на нејзиното релативно кратко егзистирање во неолитот и отсуство на континуитет во останатите предисториски периоди. Таа повторно била користена во доцната антика и средниот век, кога го губи карактерот на населба и добива повеќе стопанска и обредна намена.

Тоа го потврдува и стратиграфијата на тумбата, која во последните археолошки кампањи многу потемелно се проучуваше. За разлика од истражувањата во 1980-те кога се сметаше дека има само еден неолитски слој и по една античка и средновековна фаза, најновите проучувања утврдија многу покомплексна стратиграфија на овој локалитет. ${ }^{33}$ Имено, неолитскиот период е сочинет од три архитектонски хоризонта, со повеќе слоеви на градење и активности во нивни рамки. Во најраниот неолитски хоризонт регистрирани

\footnotetext{
${ }^{31}$ Наумов и др. 2016; Naumov et al. in press

${ }^{32}$ Китакоски 1989; Миткоски 2005.

${ }^{33}$ Наумов и др. 2016; Наумов и др. 2018; Naumov et al. in press
} 
се две фази на градење со сув, односно непечен лепеж. Во следниот хоризонт присутни се масивни градби со спален лепеж, што може да е резултат на пожар или пак намерно горење на sидовите. Над нив следи последниот неолитски хоризонт сочинет од повеќе фази со комбинирани техники на сув лепеж, неинтензивно печен лепеж и вкопување на канали за зидови. После хијатус од петипол милениуми, на тумбата се формира нов хоризонт, карактеристичен за доцната антика. Во него се регистрирани градежни елементи од стопанско-резидентна градба (вила рустика) и амбалажни јами. Врз нив, евидентиран е средновековниот хоризонт, кој исто така е покомплексен отколку што претходно се мислеше. Во него има фаза во која тумбата се користи како средновековна некропола и друга фаза во која интензивно се копаат длабоки амбалажни јами за жито, кои значително ги оштетуваат неолитските хоризонти.

\section{Неолитски период}

Неолитскиот период е во најголема мера добро сочуван, подеднакво во домен на архитектурата и материјалната култура, за разлика од античките и средновековните остатоци кои се далеку помалубројни. Благодарение на богатите органски остатоци откриени при ископувањата во последните неколку години, се направија повеќе радиокарбон анализи што овозможија прецизно утврдување на хронологијата на локалитетот. Анализите на семињата, липидите и изотопите во животинските коски го определуваат почетокот на животот во населбата околу 6000 година п.н.е. и нејзиното завршување околу 5700 година п.н.е. ${ }^{34}$ Овие дати покажуваат дека населбата била активна во крајните етапи на раниот неолит пред да настапи големиот хијатус до доцната антика. Тоа го потврдува и материјалната култура која има очигледни ранонеолитски обележја, како што се белото сликање, жртвениците со назабени нозе, антропоморфните модели и фигурините со појас и истакнати бутини (сл. 9). Ваквото датирање на Врбјанска Чука во голема мера се совпаѓа со она на неколку тумби во централниот дел на Пелагонија, ${ }^{35}$ што посочува на тоа дека скоро целата котлина била иницијално населена од првите земјоделци во исто време, односно околу 6000 годни п.н.е. Блиската хронологија меѓу овие населби може да ја објасни и веројатноста за взаемна комуникација, поради што и не изненадува сличноста во керамичките предмети што тие ги изработувале. Од друга страна, и покрај синхронизираното живеење во рамки на Пелагонија, првите земјоделски заедници во оваа котлина имале и очевидни разлики, и тоа особено во домен на архитектурата.

Тоа го потврдуваат ископувањата на неколку градби на овој локалитет, но исто така и геомагнетното скенирање кое се изврши

\footnotetext{
${ }^{34}$ Наумов и др. 2018; Naumov et al in press

${ }^{35}$ Наумов 2016.
} 
во 2016-та година. Резултатите од ова истражување, кое исто така се реализираше и на неколку други тумби во близина на Врбјанска Чука, покажуваат дека имало ров околу населбата. ${ }^{36}$ Во југоисточниот дел на овој ров имало влез во неолитското село, после кого се забележува поширок празен простор без градби (сл. 10). Градбите се распоредени во југо-западниот и централниот дел на тумбата, и тоа поставени во правец исток-запад и југо-исток - северо-запад. Во централниот дел на населбата тие се особено густо распоредени, а меѓу нив има и некои со поголеми димензии од останатите. Заедно со ископуваните градби, геомагнетните истражувања посочуваат на присуство на околу 30 објекти за кои во моментов е тешко да се потврди дали се од иста фаза. Во секој случај, имајќи ги предвид радиокарбон датите, повеќето од нив би требало да му припаѓаат на раниот неолит, освен доколку некои од магнетните сигнали не се однесуваат и на градби од доцноантичкиот и средновековниот период.
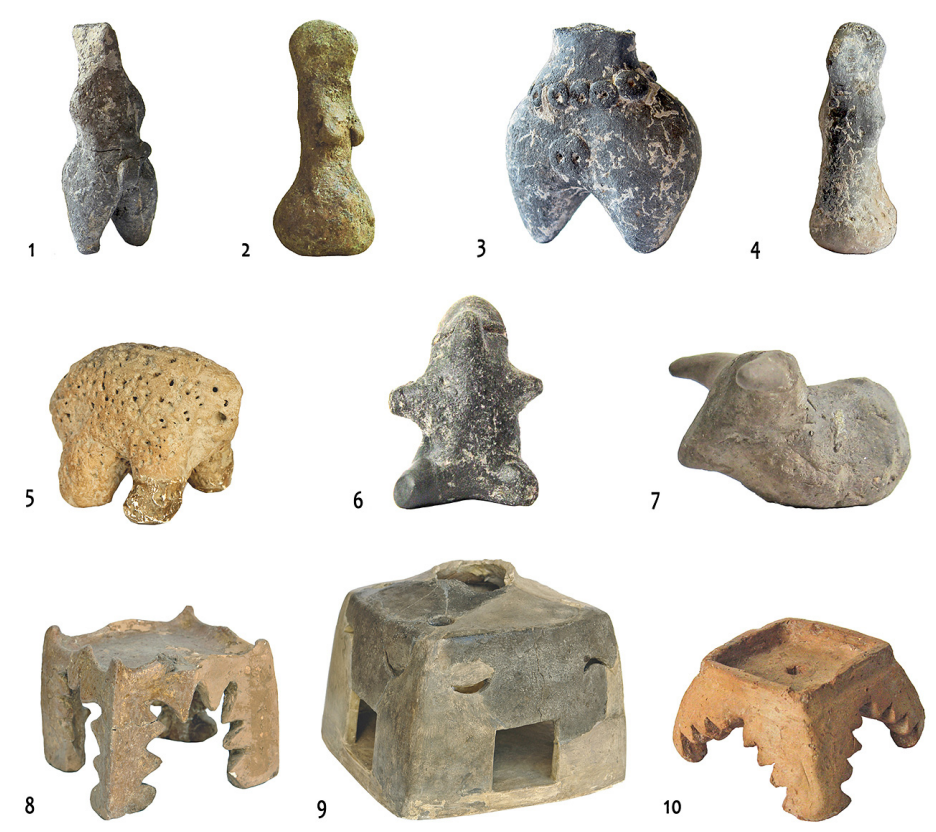

сл. 9. Неолитски фигурини, жртвеници и антропоморфни модели на куќи (фотографии Александар Миткоски)

Што се однесува до неолитската архитектура на Врбјанска Чука, детални податоци се добиени во последните кампањи, како за техничкиот карактер на градбите така, така и за нивното наслојување. Досега се регистрирани десетина градби, од кои три се детално

\footnotetext{
${ }^{36}$ Наумов и др. 2016.
} 
проучувани, а другите се дефинирани во стратиграфски контекст и ќе се ископуваат во наредните години. ${ }^{37}$ Како што беше и погоре посочено, градбите содржат различни технолошки обележја, карактеристични за различни фази во населбата, така што може да се категоризираат објекти со зидови од непечен лепеж, објекти со горени зидови од лепеж, објекти со вкопани мидови и земуници поплочени со малтер од глина. Освен нивните карактеристики на габаритот, некои од овие градби имаат комлпексен ентериер сочинет од повеќе структури од глина, а кои укажуваат на очигледните разлики во однос на градбите од другите тумби во Пелагонија.

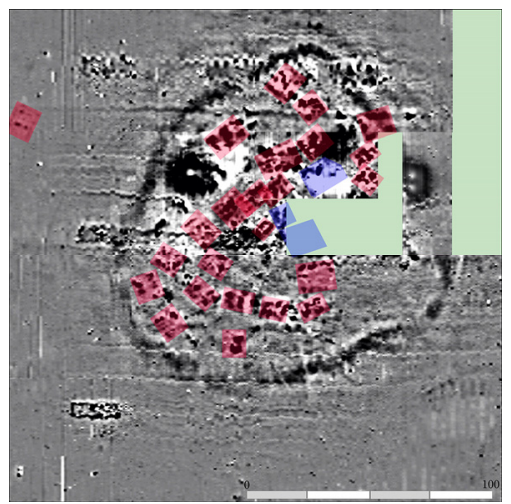

сл. 10. Резултати од геомагнетно скенирање на локалитетот Врбјанска Чука (Наумов и др. 2016, сл. 19).

Во тој контекст вреди да се истакне Градба 2 како еден од поспецифичните објекти и воедно еден од оние што се целосно истражени (сл. 11). Станува збор за градба со димензии 10 х 13 метри и претставува засега најголемиот и најкомплексниот неолитски објект во Македонија. ${ }^{38}$ Неговите зидови се сочинети од помали и поголеми колци околу кои е налепен лепеж, подоцна намерно или случајно горен. Веднаш до северниот sид има уште еден од компактна белузлава глина, а кој е залепен до него, тако што нејасно е дали е дел од Градба 2 или пак е друга што е припоена до неа, невообичаена и засега единствена ваква појава во Македонија. До јужниот sид присутен е ред од поголеми јами, веројатно за столбови кои ја држеле настрешницата или пак за кат во горниот дел, а за кого нема податоци. Во средината на градбата, има неколку масивни јами, распоредени по нејзината должина, а кои биле користени да се всадат столбовите што требало да ја држат кровната конструкција. Во внатрешноста на Градба 2 регистрирани се 11 стопански структури од глина (печки, сандаци, кружни структури и платформи за мелење на жито), што ја прави особено комплексна и уникатна во однос на нејзиниот ентериер.

\footnotetext{
${ }^{37}$ Наумов и др. 2018; Naumov et al 2018; Naumov et al in press

${ }^{38}$ Naumov et al 2018; Naumov et al in press
} 


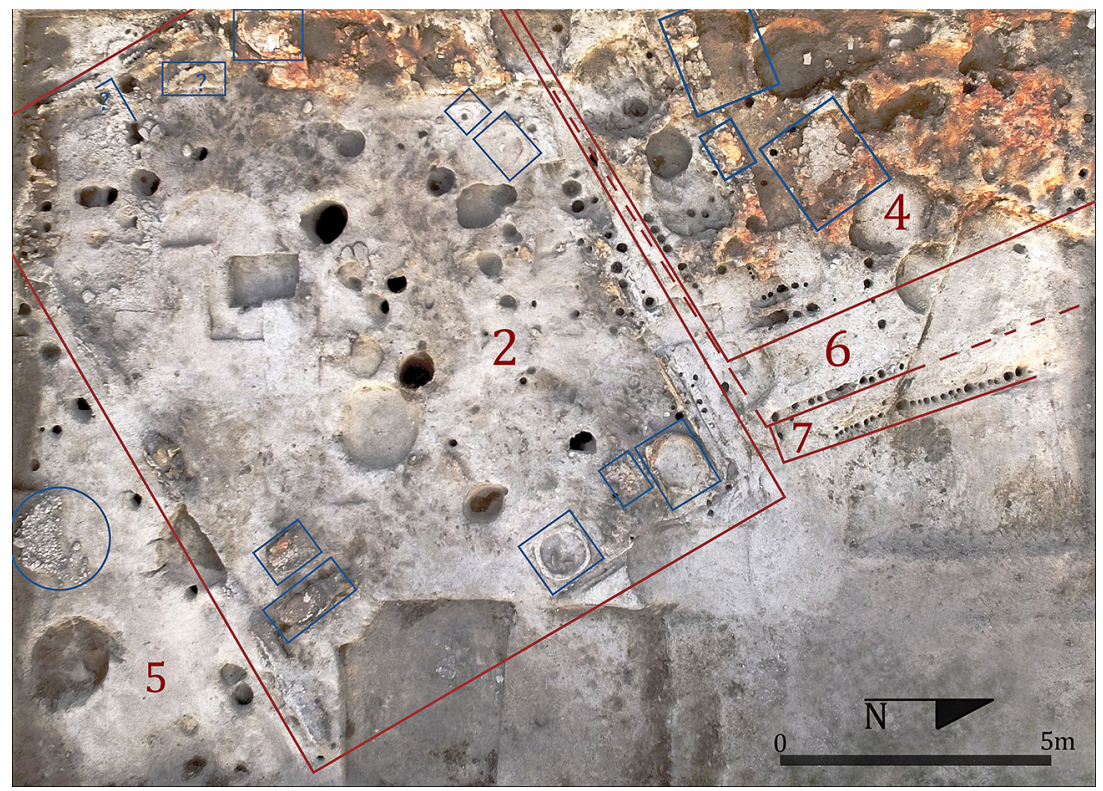

сл. 11. Позиција на Градба 2 и останатите архитектонски структури на локалитетот Врбјанска Чука (Naumov et al. 2018, Fig. 4).

Во неа исто така се пронајдени околу 30 мелници, сите свртени наопаку, што укажува на обреден чин на напуштање на градбата. Во прилог на тоа оди и неверојатно малиот број наоди пронајдени во неа, како и опожарувањето. Имено, отсуството на цели садови и малиот квантитет на фрагменти посочува на чистење на објектот пред неговото напуштање, а во сличен контекст се става и намерното палење на градбата, што како појава е регистрирано на повеќе неолитски локалитети на Балканот. ${ }^{39}$ Освен Градба 2, исто така и Градба 1, Градба 4, Градба 6 и Градба 9 се сочинети од мидови со горен лепеж. И во Градба 4 се регистрирани поголеми и помали глинени инсталации, додека во Градба 1 е откриена една од најимпресивните ентериерни структури на Балканот. Станува збор за масивен амбар сочинет од еден поголем сандак и 8 помали припоени до него, од кои половината се уништени од градежни активности (сл. 12). Големиот сандак е украсен со скалести апликации идентични со оние на жртвениците (воедно е откриен и жртвеник во него), што ѝ дава исклучителен симболички карактер на оваа голема структура, долга 4 метри. ${ }^{40}$ Ова дополнително го истакнува уникат-

${ }^{39}$ Naumov et al 2018; Naumov et al in press

${ }^{40}$ Kitanoski, Blagoja; Simoska, Dragica and Jovanović, Borislav. Der kultplatz auf der fundstatte Vrbjanska Cuka bei Prilep. In Srejović, D. and Tasić, N. (eds.) Vinča and its World. International Symposium The Danubian Region from 6000-3000 BC (1990) 107-112. Beograd: Serbian Academy of Science and Arts, Centre for Archaeological Research, Faculty of Philosophy. Beograd. Bigz; Миткоски 2005; Naumov 2013. 
ниот карактер на неолитската архитектура на Врбјанска Чука и го издвојува овој локалитет од останатите во Пелагонија, но и пошироко. Тоа говори и за комплексната социјална на структура на заедницата што живеела во оваа населба, а за што подоцна ќе стане збор.

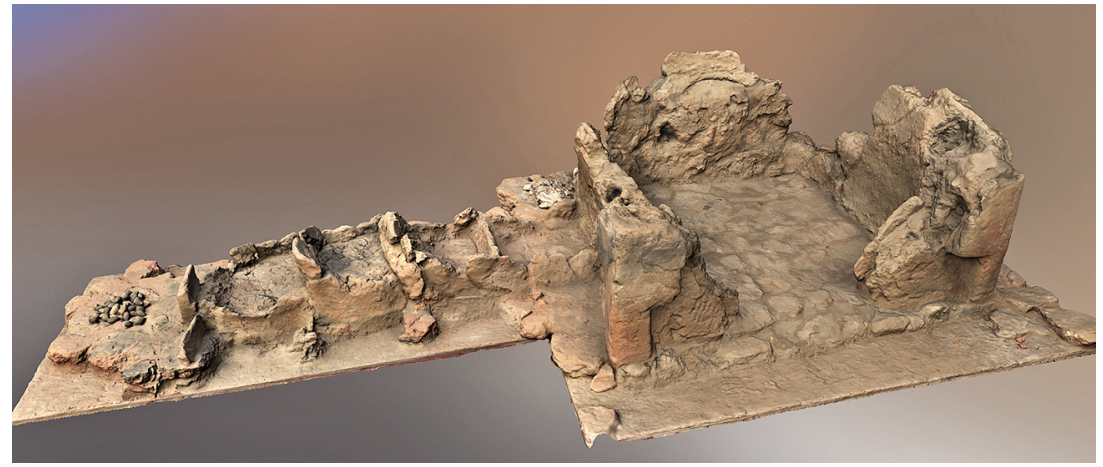

сл. 12. 3Д илустрација на неолитскиот амбар од локалитетот Врбјанска Чука (Наумов и др. 2018, сл. 15).

Во прилог на високите технички и естетски достигнувања на неолитското население во оваа тумба оди и материјалната култура која е еднакво импресивна по својот изглед и изработка. Таа ги има карактеристиките на Велушко-породинската група, но воедно се издвојува со повеќе уникатни обележја кои барем засега се присутни само на Врбјанска Чука. Во најголема мера тоа се однесува на садовите кои имаат типологија вообичаена за пелагонската котлина, но содржат декорација која е автентична. Меѓу нив спаѓаат садовите со фина фактура и тоа особено паниците, грнињата и купите, а кои невообичаено за другите локалитети во Македонија, се изработувале во голем број на овој локалитет. Иако на некои од нив ретко е присутно и белото сликање, сепак доминираат тенки линии, извиени и прави ленти изведени со црна разредена боја. Освен во многу ретки случаи, тие воопшто не се присутни во Пелагонија, така што се истакнуваат како обележја типични само за Врбјанска Чука. Секако, присутна е керамиката со груба фактура, користена за готвење и амбалажирање, но таа ја има вообичаената генерална типологија и ретко се издвојува со индивидуални карактеристики. ${ }^{41}$

Во домен на материјалната култура особено се истакнуваат артефактите со изразито симболички карактер, меѓу кои спаѓаат моделите на куќи, жртвениците, фигурините итн. За разлика од антропоморфните модели во централниот дел на Пелагонија, оние откриени на Врбјанска Чука се постилизирани и ретко имаат елементи што прикажуваат човечки и архитектнонски обележја. Цилиндрите скоро воопшто немаат антропоморфни карактеристики, а де-

${ }^{41}$ Миткоски 2005; Наумов и др. 2016. 
лот на куќата е особено стилизиран. Но во секој случај, тие ја следат симболичката нишка вообичаена за овој вид предмети во Пелагонија и соодветствуваат на комеморативната идеологија и нивната намена како светилки. Тука треба да се истакнат и бројните жртвеници во форма на масички со назабени ногарки, кои имаат траги на горење и претежно обредна функција. Фигурините исто така се издвојуваат со својата локална специфичност иако делумно содржат елементи присутни на нивните еквиваленти од централниот дел на Пелагонија. Тие се претежно стилизирани, со цилиндрични тела, кратки раце, широки бутини и лица на кои единствено очите се присутни, иако во ретки случаи. ${ }^{42}$

Меѓу предметите за рачна употреба може да се истакнат проектилите за праќа, а кои ги има во многу голем број, нешто што е вообичаено за локалитетите во Пелагонија, но ретко за останатите во Македонија. Што се однесува до алатките, тие го содржат вообичаениот репертоар за неолитските локалитети. Секирите се релативно чести и имаат средни и помали димензии, додека поголеми примероци ретко се откриваат. Исто така и кремените алатки се присутни во поголем број и на нив беше извршена анализа на трагите на користење. Притоа, се констатираше дека повеќето од нив биле користени за жнеење, што сосем одговара на економскиот карактер на населението што живеело на оваа тумба. ${ }^{43}$ Во тој контекст одат и мелниците кои се откриваат во огромен број, и тоа во сите фази и објекти регистрирани во населбата. Како што беше и погоре кажано, особено се истакнува Градба 2 во која се открииени околу 30 вакви предмети и тоа сите превртени наопаку. При анализата на скроб извршена на некои од нив, се констатираше дека не биле сите користени за мелење на жито, туку на некои се мелеле и желади. ${ }^{44}$

Говорејќ́ за органските остатоци и стопанството треба да се истакне дека на Врбјанска Чука се вршени и археоботанички анализи кои дадоа темелен увид во исхраната на населението и вегетацијата околу локалитетот. Во рамки на исхраната најзастапени се житариците (пченица и јачмен), леќата и грашакот, а откриени се и диви растенија, како што се капина, бозел, трнинка, бела лобода и оние од фамилиите на бросови, штирови и троскоти. Органските остатоци во рамки на градбите укажуваат на процесирање и употреба на билките во исхраната и економијата, додека други, особено диви растенија и полжави, даваат индикации и за мочурливата околина во близина на населбата. ${ }^{45}$ Во контекст на исхраната треба

42 Наумов и др. 2016.

${ }^{43}$ Наумов и др. 2016; Наумов и др. 2018.

${ }^{44}$ Наумов и др. 2018.

${ }^{45}$ Наумов и др. 2016; Наумов и др. 2018; Antolín, Ferran; Sabanov, Amalia; Naumov, Goce and Soteras, Raul. 'Crop choice, gathered plants and household activities during the beginnings of farming in Pelagonia valley (North Macedonia)'. Antiquity 94 (376) (Project Gallery) (2020), 1-8. 
да се истакнат и зооархеолошките анализи кои ја потенцираат преферираната употреба на говедското месо во однос на овците, козите и свињите, што пак е поразлично од останатите балкански локалитети каде доминираат козите. Во исхраната било вклучено и месото на еленот, срната, дивата свиња и лисицата, иако некои од овие животни биле користени и за други суровини (алатки, тетиви или крзно). Тука треба да се посочи и на анализите на липидите кои укажуваат на остатоци од млечни производи, масла, масти од преживари и растенија. ${ }^{46}$ Сите наведени анализи упатуваат на разноврсноста на исхраната на неолитската популација на Врбјанска Чука, но исто така и на комплексната економија и богатата флора и фауна во блиското опкружување на тумбата.

\section{Антички период}

Што се однесува до античкиот период на Врбјанска Чука, тука информациите се далеку поскромни, пред сѐ поради лошата сочуваност на остатоците од овој период. Имено, античките слоеви се во голема мера оштетени од средновековните упади правени за јамите и неколкуте структури. Поради тоа, а и делумно поради малиот обем на сондажни истражувања, не се откриени позначајни елементи од античката архитектура. Како што беше и претходно спомнато, во овој период тумбата најверојатно се користела за вила рустика, стопански објект наменет за акумулирање, обработка и дистрибуција на суровините добиени од земјоделските активности околу Врбјанска Чука. За жал, поголеми остатоци од ваков објект не се откриени, но елементи од зидови, подови, како и бројни покривни керамиди (тегули), тули и одводни цевки (имбрекси) се регистрирани на повеќе места. Исто така и фрагментите од античка керамика, пирамидални тегови и неколкуте монети укажуваат на активности во овој период. ${ }^{47}$

Во таа смисла керамиката, теговите и монетите во моментов се користат како главен хронолошки индикатор. Монетите се далеку попрецизни во домен на релативната хронологија, така што според нивните обележја може да се потврди дека тие биле ковани во III и IV век, т.е. во времето на Гордијан III и Костанциј II. Периодот на II и III век е исто така сугериран преку метални предмети, како што се двокрилните појасни бронзени токи и железните алаткидлета. Керамиката сугерира на многу поширок временски спектар и тоа меѓу I и IV век. Кон ваквиот заклучок наведуваат чиниите, чашите и цедалките со црвен премаз, чашите со печатена декорација, како и бокалите, грнците и лонците изработени со груба фактура. ${ }^{48}$

За разлика од присуството на материјалната култура, архитектурата е скоро отсутна освен во неколку ретки контексти. Имено во

\footnotetext{
${ }^{46}$ Наумов и др. 2018; Naumov et al in press

${ }^{47}$ Миткоски 2005; Наумов и др. 2016; Наумов и др. 2018.

${ }^{48}$ Миткоски 2005; Наумов и др. 2018.
} 
еден од истражуваните квадранти е откриен sид од камења, како и под од набиена земја до него. ${ }^{49}$ Не е јасно дали овој мид претставува дел од поголемата вила рустика или пак станува збор за страничен објект со барем засега нејасна функција (сл. 13). Во однос на интервенции врз самата тумба, може да се издвојат и неколку јами користени за чување на житарици. Во нив се откриени неколку фрагменти од античка керамика и тегули, но тие биле оставени празни. Се претпоставува дека во нив биле сместени питоси или пак садови исплетени од слама наменети за чување на житариците до нивното транспортирање во околните села или градови.

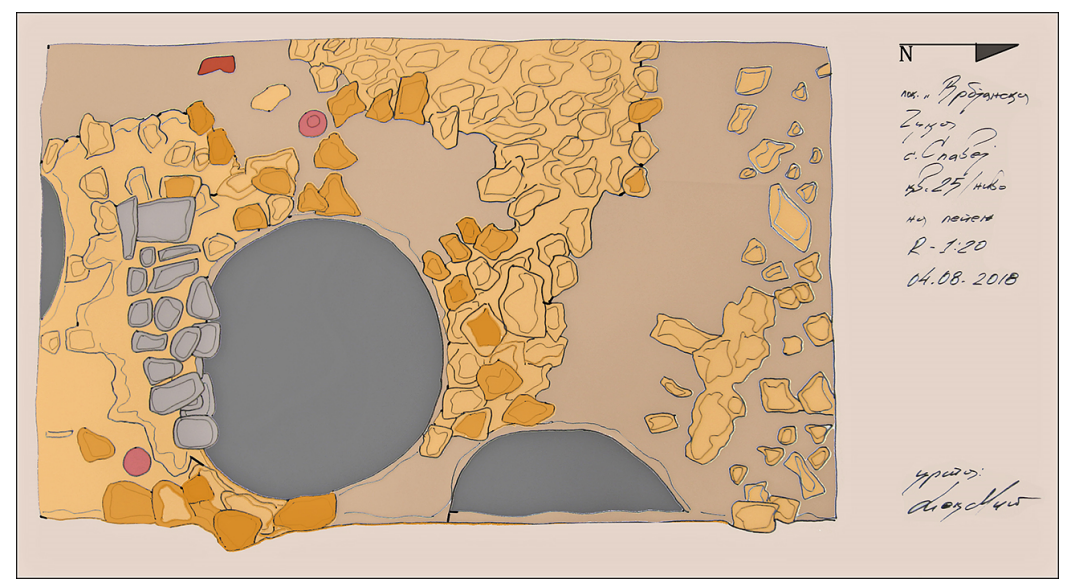

сл. 13. Остатоци од антички зид и јами од локалитетот Врбјанска Чука (Naumov et al. 2018, Fig. 12).

Иако скромни по својот карактер, сепак наодите и архитектонските остатоци даваат некакви елементарни информации за животот во античкиот период. Секако, неопходно е многу поекстензивно истражување за да се дојде до поконкретни резултати од овој период, со оглед на тоа што геомагнетните скенирања укажуваат на постоење на помасивна градба, но со сѐ уште недефинирана хронологија. Присуството на монети и керамика потврдуваат дека тумбата не била користена во раната антика, туку за време на Римската Империја во рамки на една од нејзините провинции. Имајќк го предвид големиот временски хијатус меѓу неолитскиот и античкиот период, тумбата останува активна и после IV век и тоа во неколку етапи на средниот век.

\section{Средновековен период}

За разлика од античките остатоци, средновековните елементи се далеку поприсутни, иако скоро целосно отсуствуваат архитектонските појави. Од овој период откриени се бројни фрагменти ке-

${ }^{49}$ Наумов и др. 2018. 
рамика, како и неколку метални предмети (прстени, алки и ножеви), кои индиректно упатуваат на релативната хронологија (сл. 14). Исто така, тука не треба да се занемарат и бројните амбалажни јами и погребувања кои всушност претставуваат највпечатливиот сегмент од средновековните слоеви на Врбјанска Чука.

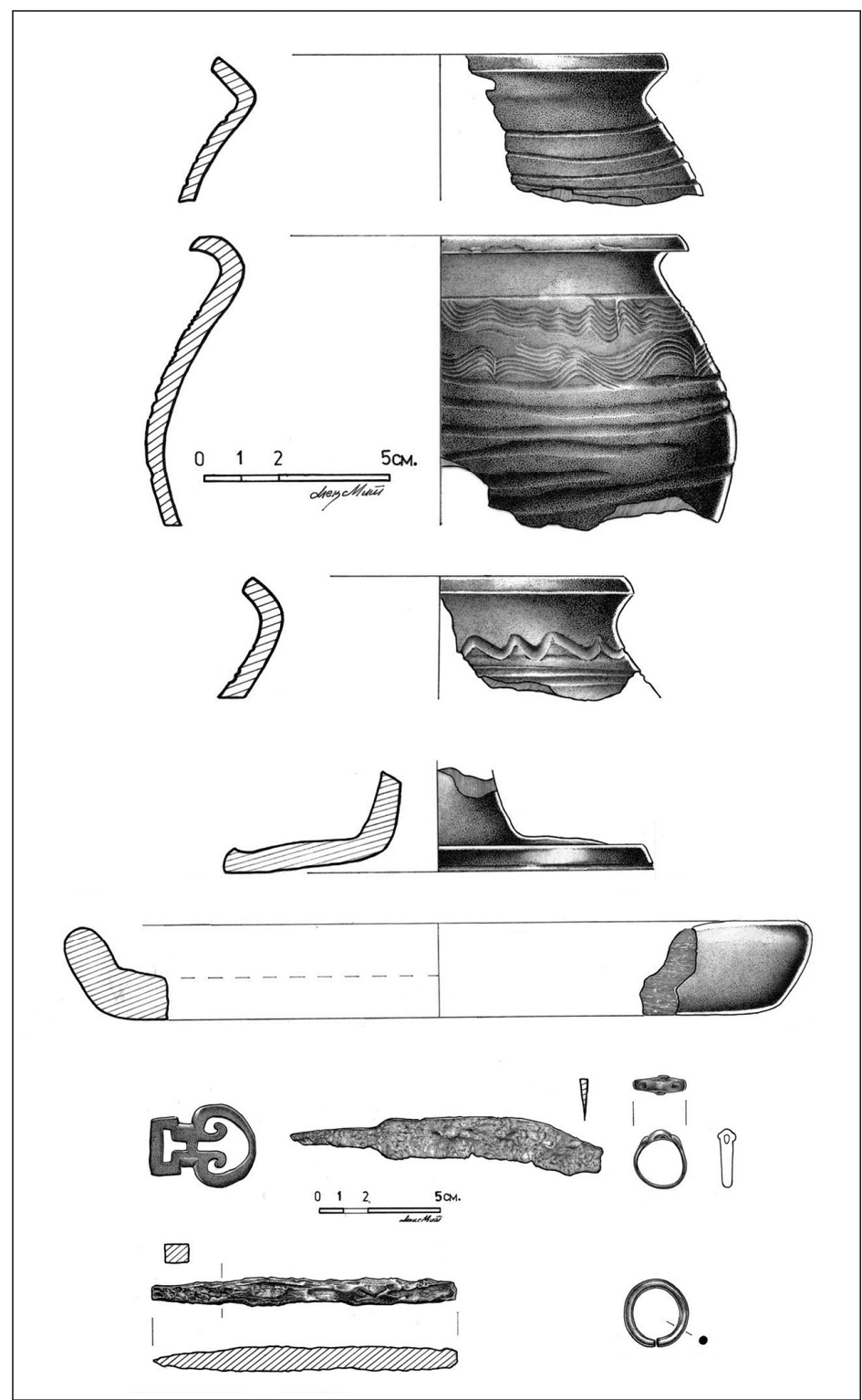

сл. 14. Античка тока и средновековни садови, ножиња и прстени од локалитетот Врбјанска Чука (Миткоски 2005, T. IV и V ). 
Што се однесува до хронологијата, материјалната култура дава широк временски распон од раниот средниот век (V-VIII век), како и од полното и доцното средновековие (X-XV век). Кон тоа упатуваат разните форми на керамика во која главно преовладуваат грубите садови за чување и готвење на храната (грниња со вообичаената средновековна врежана декорација, стомни, црепни, капаци и т.н.). Исто така во прилог се и неколкуте откриени метални предмети, алки (датирани меѓу X и XIV век), прстени (датирани меѓу X и XII век), како и ножеви и други железни алатки коишто имаат поширок временски опсег. ${ }^{50}$ За разлика од овие индикатори на релативната средновековна хронологија, на Врбјанска Чука направено е и датирање на човечки заб кој дава апсолутни дати за овој период. Имено станува збор за премолар којшто има лабораториски хронолошки распон меѓу 907 и 1119 година и мошне прецизно го определува времето на погребувањето на средновековните индивидуи. На тој начин, може да се истакне дека материјалната култура и датите од погребувањата се поклопуваат и укажуваат на конкретна активност на Врбјанска Чука меѓу X и XII век. ${ }^{51}$

Во домен на активностите во средниот век на тумбата, не може многу да се каже, освен за јамите и погребувањата. Архитектонските остатоци се многу ретки и најчесто посочуваат на постоење скромни структури од набиен под, лепеж, јами и ретко камења и вкопани канали (сл. 15). ${ }^{52}$ Целосна градба од средниот век не е откриена на Врбјанска Чука, ниту пак поголем дел од објект за кого би се сугерирала некаква функција. Претежно станува збор за мошне ретки елементи од архитектура кои посочуваат на нивно значително оштетување со подоцнежното орање во домен на тумбата или пак кон нивно отсуство со оглед на големиот квантитет на јами и погребувања коишто не овозможувале слободен простор за градење, барем во централниот дел на тумбата и во стратиграфската позиција на овие стопански и обредни обележја. И оние ретки остатоци на подови, канали и зидови, може да се остатоци од некакви придружни стопански градби во функција на јамите, а истото го сугерира и средновековната керамика која не е во толкав број за да се потврди постоење на населба од овој период на тумбата.

Тука треба да се истакне дека неколкуте ретки градежни структури повеќе се во функција на обредните фунерарни форми отколку во релација со резидентната или стопанската архитектура. Имено, станува збор за неколку правоаголни и кружни групации на камен кои се поставени под гробовите со инхумација или кенотафите, како и за поплочувања со намерно кршени покривни керамиди и садови кои биле во функција на подлоги врз кои се поставувале починатите (сл. 16). ${ }^{53}$ Овие невообичаени појави за средновековната

\footnotetext{
${ }^{50}$ Миткоски 2005; Наумов и др. 2016.

${ }^{51}$ Наумов и др. 2018.

52 Наумов и др. 2018.

${ }^{53}$ Наумов и др. 2018.
} 

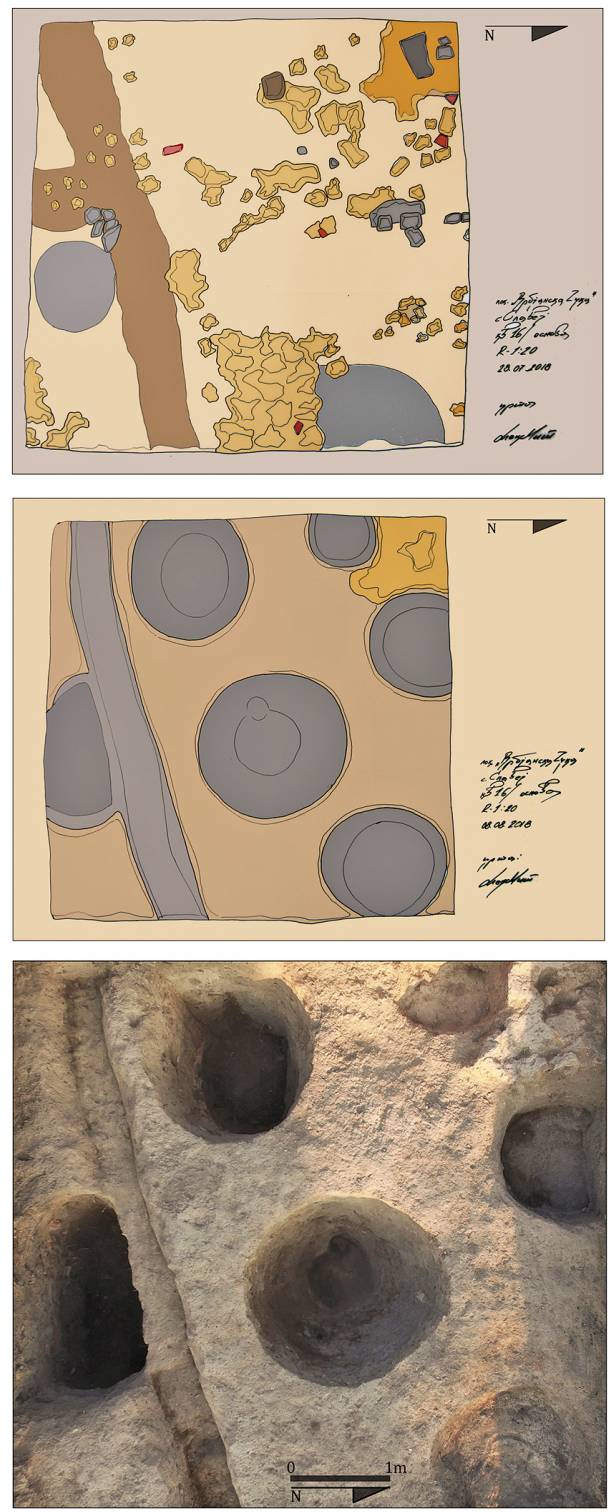

сл. 15. Средновековни јами и канали од локалитетот Врбјанска Чука (Naumov et al. 2018, Fig. 13-15).

фунерарна археологија се мошне интересни доколку се истакне нивната специфичност и релативно честа појава на Врбјанска Чука. За разлика од самите погребувања, кои ги имаат стандардните христијански форми на положување и меѓу кои целосно отсуствуваат било какви прилози на накит и храна, овие пропратни фунерарни контексти претставуваат вистинско изненадување и новост. Тука 
треба да се истакне и тоа дека меѓу приближно дваесетте откриени погребувања на оваа тумба, воопшто не се констатирани укопи за гробови, ниту пак се регистрирани остатоци од сандаци (шајки, оплати или даски), не толку ретки на другите средновековни некрополи. Тоа воедно укажува и на погребување на христијанска популација која немала некаков истакнат статус или пак била дел од некои поспецифични и нетипични фунерарни обреди, а кои исклучувале употреба на сандаци и гробни прилози.

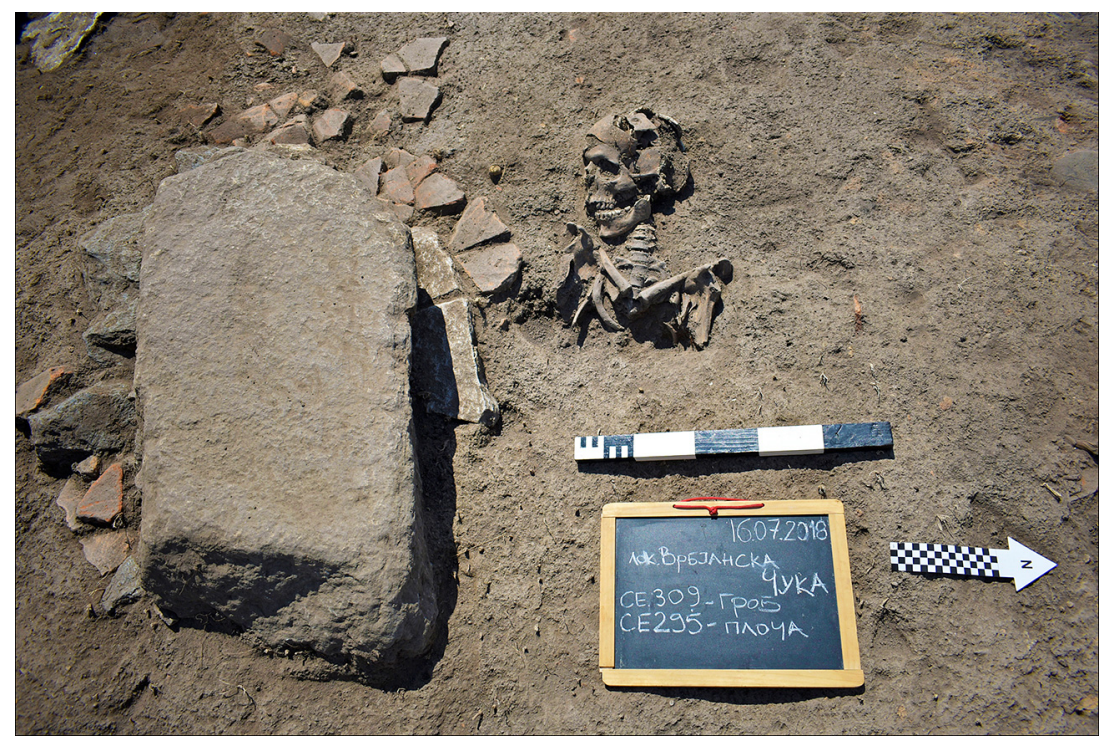

сл. 16. Средновековен гроб, поплочување и кенотаф од локалитетот Врбјанска Чука (Naumov et al. 2018, Fig. 11).

Исто така не може да се каже дека овие погребувања се одвивале невнимателно и набрзина од страна на средновековни популации кои поминувале низ Пелагонија, особено доколку се имаат предвид поплочувањата со фрагментирани тегули и садови под гробовите. Во домен на симболичките концепти треба да се истакнат и мноштвото амбалажни јами кои се копале пред, но и после некои од погребувањата. Во таа смисла, може да се истакне и тоа дека, покрај својата стопанска функција за чување на житото кое подоцна требало да се дистрибуира меѓу средновековните села, јамите сугерирале и некаков симболички карактер кој бил поврзан со улогата на житото, како во секојдневниот така и во обредниот живот. Оттаму и не случајно е погребувањето на скелети и неколку черепи токму на дното на овие јами. Еден од овие черепи бил дури и напречно преполовен и неговиот фронтален и заден дел положени еден до друг на самото дно во една од поголемите јами на тумбата. Ваквото намерно декапитирање на човечкото тело и селективното погребување на негови делови во амбалажните јами има далеку поширок ре- 
лигиозен контекст кој изискува многу повнимателно и темелно истражување на фунерарните форми во средниот век, а кои делумно излегуваат од востановените обредни норми. Дали станува збор за отстапување од фунерарните традиции или пак за популации со нестандардно разбирање на задгробниот живот, единствено останува да се проучи преку постоењето на евентуалните аналогии во рамки на Македонија и Балканот.

\section{Заклучок}

Краткиот преглед на археолошките обележја на Врбјанска Чука претставува добар пример за тоа зошто и како се појавуваат тумбите во Пелагонија, но и на кој начин тие продолжуваат да функционираат во антиката и средниот век. Од приложеното станува јасно дека оваа тумба е комплексен локалитет кој во себе содржи предисториска населба, антички стопански објекти и средновековна некропола со мноштво амбалажни јами. На самиот почеток тоа е населба кој нема преднеолитски развојни фази туку веднаш, уште од најраните етапи, се основа како оформен стопански центар концентриран на земјоделството како примарна гранка. Иако Врбјанска Чука се издвојува од останатите пелагониски тумби, особено во домен на архитектурата, сепак и останатите вакви населби имаат сличен формациски процес. Ниту една од досега истражуваните тумби нема почетна фаза во која населбата се прилагодува на околината и постепено се изградува во стабилно неолитско село. Напротив, сите десетина ранонеолитски тумби, ископувани од последниот до првиот неолитски слој, веднаш се етаблираат како оформени населби со импресивна материјална култура која не е резултат на општествено експериментирање, туку уште во самите почетоци покажува исклучително високи технички и естетски квалитети. Тоа потврдува дека оние што ги користеле овие предмети и живееле во овие населби дошле како веќе детерминирани заедници со мошне јасна цел - откривање на плодна почва и богат извор на ресурси.

Од каде дошле и како дошле овие заедници е тема која во моментов не може многу да се дискутира, иако очигледни се сличностите со материјалната култура и населбинскиот концепт присутни порано во Тесалија и делумно во Анадолија. Сличноста во раната хронологија на повеќето од пелагонските тумби повторно укажува на тоа дека овој процес се случил релативно брзо и тоа во определен период, односно околу 6000 година п.н.е. Тоа значи дека земјоделските заедници барале конкретен простор во кого можат да ги реализираат сопствените економски и егзистенцијални цели, процес кој веројатно следел после пионерското испитување на животната средина. Тука треба да се истакне дека на ниту една од тумбите во Пелагонија, барем досега не е утврдена мезолитска или ранонеолитска акерамична фаза. Поради тоа, евентуалните т.н. кампови на неолитските „скаути“ би требало да се наоѓаат на други локации 
од каде се повикувало или привлекувало земјоделското население да го насели котлинскиот мочурлив простор. Овој процес можеби бил рапиден, но исто така би можел да биде и постепен, така што Пелагонија во кратки, но густи етапи станувала привлечна за повеќе заедници.

Тоа го потврдува и веќе утврдениот модел на формирање тумби присутен во Тесалија и Анадолија, а кој очигледно се пресликал и во Пелагонија. Првите земјоделски заедници се насочиле кон освојување нови простори и тоа особено котлини исполнети со мочуришта, а околу кои имало изобилство на плодна почва. Токму таму формирале помали населби кои интензивно ги обновувале и наслојувале. Наместо да ги шират своите села, овие заедници ги граделе новите градби врз постарите, така што базицирале конкретна помала територија, но исто така воспоставиле континуирана силна врска со своите предци. Досега, на ниту една неолитска тумба во Пелагонија не е откриено интрамурално погребување, што би укажало на оваа меѓугенерациска симболичка врска. Меѓутоа повеќето од нив изобилуваат со антропоморфни модели на куќи, хибридизирани претстави на човеколика архитектура, кои биле користени како комеморативни светилки. Веројатно на тој начин се акцентирала почитта кон предците и ритуално се зајакнувала врската со нив. Во таа смисла, тумбите претставуваат симболички ентитети кои не само што во својата суштина го имаат земјоделското стопанство, туку и поврзаноста меѓу генерациите што неа ја формираат и континуирано обновуваат.

Поради тоа, овие населби се поврзани со процесот на доместикацијата бидејќи со нив се финализира долгиот тек на припитомување растенија и животни и се афирмираат како веќе оформена стопанско-симболичка целина која се дисперзира од Блискиот Исток до Југоисточна Европа, вклучително и во Пелагонија. Примарниот мотив за нивно основање и континуирано обновување е токму земјоделството, стопански концепт кој имал за цел да лоцира и интензивно експлоатира одредено плодно подрачје. Врз него веднаш или постепено се надоградило симболичкото перципирање на овој архитекнотнски простор како основа за втемелувањето симболички врски меѓу првите и наредните жители на тумбите. Во таа смисла, Пелагонија претставува извонредно заокружување на овој стопанско-симболички концепт манифестиран преку антропоморфните модели на куќи и мноштвото тумби распоредени околу мочурливите предели во котлината.

Тука особено се издвојува Врбјанска Чука која го следи овој процес, но се истакнува како засебен центар во кого е извршена технолошка инвестиција во домен на архитектурата. Масивните куќи и амбари, како и мноштвото инсталации од глина во нивниот ентериер, ја акцентира засебноста на оваа населба, но и на населението што живеело во неа. Тие не само што ги граделе овие фасцинантни 
структури, туку имале и врвна материјална култура сочинета од квалитетна фина керамика, антропоморфни модели, фигурини, жртвеници итн. Овие технички и естетски достигнувања не се резултат единствено на менталниот капацитет и когнитивно-мануелните способности на жителите на Врбјанска Чука, туку и на економската моќ што тие ја имале во однос на досега познатите неолитски населби во Пелагонија. Таа дефинитивно се издвојувала од останатите како економски центар кој во својата основа го има акумулирањето и процесирањето на житариците. Секако, овој стопански чин не треба да се сфати единствено низ призмата на економијата, бидејќи масивните и бројните глинени инсталации (амбари и сандаци), за чување и обработка на пченицата и јачменот, биле декорирани со идентични аплицирани мотиви како и оние на малите глинени жртвеници.

Но животот на Врбјанска Чука и бројни други неолитски тумби не завршува во неолитот, туку напротив тој продолжува и понатаму. Во случајот со овој локалитет, постои голем временски хијатус пред тој да стане повторно активен во антиката и средниот век, додека на неколку други тумби, иако со прекини, следат енеолитската и бронзенодобната фаза. Во рамки на предисторијата тумбите остануваат да бидат функционални во форма на населби, меѓутоа нивната улога се менува во римскиот период и полниот среден век. Позицијата на овие локалитети во плодните пелагонски полиња овозможува тие да бидат антички центри кои ке го координираат и дистрибуираат житото низ Римската Империја, така што на нив ќе се градат објекти од типот вила рустика. Сличната улога тие ја задржуваат и во средниот век, и тоа особено во домен на ползувањето на амбалажните јами за чување на жито, меѓутоа тумбите ќе се претворат и во некрополи каде што најверојатно се погребувало околното население. Со оваа сакрална функција дополнително се истакнувал нивниот симболички карактер особено во релација меѓу житото и човековиот живот како битна нишка која го објаснува континуитетот и повторното раѓање. На тој начин, тумбите дури и после шест милениуми добиваат слична улога во зацврстувањето на симболичките врски меѓу луѓето и нивните предци, и покрај тоа што станува збор за сосема различни популации кои живееле во предисторијата и средниот век. 


\title{
БИБЛИОГРАФИЈА
}

\author{
- по кириличен редослед -
}

Анисимов, А. Ф. (1959). Космологические представления народов севера. Москва; Ленинград: Издательство академии наук СССР.

Абази, Љуљета и Толевски, Игор. Стратиграфска слика за локалитетот Тумба-Брвеница. Во Наумов, Г. и Фиданоски, Љ. (ур.) Неолитот во Македонија: во чест на Воислав Санев (2019), 11-34. Скопје: Центар за истражување на предисторијата.

Antolín, Ferran; Sabanov, Amalia; Naumov, Goce and Soteras, Raul. 'Crop choice, gathered plants and household activities during the beginnings of farming in Pelagonia valley (North Macedonia)'. Antiquity 94 (376) (Project Gallery) (2020), 1-8.

Бъчваров, Крум. Неолитни погребални обреди. София: Бард, 2003.

Bailey, Douglas. What is a Tell? Settlement in fifth millennium Bulgaria. In Brück, J. and Goodman, M. (eds.) Making places in the prehistoric world: themes in settlement archaeology (2002), 94-111. Cambridge: University of Cambridge.

Gimbutas, Maria. Anza, Neolithic Macedonia, As reflected by Excavation at Anza, Southeast Yugoslavia, 1976. Los Angeles: The Regents of the University of California.

Dumurdzanov, Nikola; Serafimovski, Todor and Burchfiel, Clark, B. Evolution of Neogene-Pleistocene Basins of Macedonia. Digital Map and Chart Series 1 Acompanying notes). (Boulder: Geological Society of America), 2004

Здравковски, Драгиша. „Неолитска населба „Под село-Тумба“ с. Стенче“. Зборник на Музејот на Македонија 2 (археологија) (2005), 25-31. Скопје.

Здравковски, Драгиша и Саржоски, Саржо. „Тумба Палчиште, неолитска, енеолитска и бронзенодобна населба“. Arheološki Pregled 28 (1989), 43. Ljubljana.

Китаноски, Благоја. „Врбјанска Чука“. Arheološki pregled 1987: (1989), 47-48. Ljubljana.

Китаноски, Благоја, Симоска, Драгица, и Тодоровић, Јован. Нови археолошки истражувања на населбата Чука во Тополчани кај Прилеп. Macedonia Acta Archaeologica 4 (1978), 9-32. Прилеп.

Kitanoski, Blagoja; Simoska, Dragica and Jovanović, Borislav. Der kultplatz auf der fundstatte Vrbjanska Cuka bei Prilep. In Srejović, D. and Tasić, N. (eds.) Vinča and its World. International Symposium The Danubian Region from 6000-3000 BC (1990) 107-112. Beograd: Serbian Academy of Science and Arts, Centre for Archaeological Research, Faculty of Philosophy. Beograd. Bigz.

Kotsakis, Kostas. What Tells Can Tell: Social Space and Settlement in the Greek Neolithic. In Halstead, P. (ed.) Neolithic Society in Greece (1999), 66-76. Sheffield: Sheffield Academic Press.

Коцо, Димче и Грозданов Цветан. Археолошка карта на Република Македонија. Скопје: Македонска академија на науките и уметностите, 1996.

Миткоски, Александар. „Врбјанска Чука кај селото Славеј, Прилепско“. Зборник на Музеј на Македонија 2 (2005), 33-46. Скопје.

Миткоски, Александар „Нови сознанија за енеолитот во прилепскиот дел на Пелагонија и Мариово“, Зборник на трудови 20 (2017). Битола.

Naumov, Goce. Housing the Dead: Burials inside houses and vessels from Neolithic Balkans. In Malone, C. and Barrowclough, D. (eds.), Cult in Context: Reconsidering Ritual in Archaeology (2007), 255-265, 2007. Oxford: Oxbow Books.

Naumov, Goce Patterns and Corporeality: Neolithic Visual Culture from the Republic of Macedonia. Oxford: British Archaeological Reports-International Series, 2009.

Naumov, Goce. Embodied houses: social and symbolic agency of Neolithic architecture in the Republic of Macedonia. In Hoffman, D. and Smyth, J. (eds.) Tracking the 
Neolithic house in Europe-sedentism, architecture and practice (2013), 65-94. New York: Springer.

Naumov, G. 'Tell communities and wetlands in the Neolithic Pelagonia, Republic of Macedonia'. Documenta Praehistorica 43 (2016), 327-342.

Наумов, Гоце. Калибрирана хронологија на неолитските тумби во Македонија. Во Наумов, Г., и Фиданоски, Љ. (ур.) Неолитот во Македонија: нови сознанија и перспективи (2016), 67-96. Скопје: Центар за истражување на предисторијата.

Naumov, Goce. Formation of Wetland Identities in the Neolithic Balkans. In Shydlovskyi, P. (ed.) Prehistoric Networks in Southern and Eastern Europe. Vita Antiqua Series 10 (2018), 48-60. Kiev: Taras Shevchenko University.

Наумов, Гоце, Тержиецки, Марчин, Пшибила, Марчин, Чвиеј, Малгоржата, Бугај, Урсула, Шчепаник, Пјотр и Подсјадло, Марта. „Археолошко, топографско и геофизичко истражување на неолитски тумби во Пелагонија“. Патримониум 12 (2014), 345-372. Скопје.

Наумов, Гоце и Стојкоски, Слободан. „Нови предисториски тумби во Пелагонија“. Зборник на трудови на Завод и музеј-Битола 18 (2015), 169-183. Битола.

Наумов, Гоце; Миткоски, Александар; Мургоски, Александар; Бенеш, Јаромир; Милевски, Ѓоре; Пшибила, Марчин; Комаркова, Вероника; Вихронова, Михаела и Стоимановски, Ивица. „Истражување на Врбјанска Чука кај Славеј-2016“. Патримониум 14 (2016), 13-42. Скопје.

Naumov, Goce, Jan John and Ondrej Chvojka. Geophysical scanning of prehistoric tells in Central Pelagonia. In Fidanoski, Lj. and Naumov, G. (eds.) Neolithic in Macedonia II: step forward in the study of the first farming societies (2017), 161-180. Skopje.

Гоце Наумов, Александар Миткоски, Александар Мургоски и Ѓоре Милевски, Рекогносцирање на предисториски локалитети во Северна Пелагонија, Патримониум 15 (2017), 11-36. Скопје.

Наумов, Гоце; Миткоски, Александар; Талевски, Христијан; Александар Мургоски; Никола Думурџанов, Јаромир Бенеш, Ивана Живаљевиќ, Југослав Пендиќ, Дарко Стојаноски, Хуан Хибаха, Николо Маsуко, Алберт Хафнер, Сонке Зидат, Весна Димитриевиќ, Софија Стефановиќ, Кристина Будилова, Михаела Вихронова, Тереза Мајеровичова и Јиржи Бумерл, Истражување на локалитетот Врбјанска Чука во 2017 година. Balcanoslavica 47 (1) (2018), 253-285.

Naumov, Goce, Mitkoski, Aleksandar, Talevski, Hristijan, Anvari, Jana, Przybila, Marcin, Stojanovski, Darko, Antolín, Ferran, Sabanov, Amalia, Živaljević, Ivana, Dimitrijević, Vesna, Gibaja, Juan, Mazzucco, Niccolo, Milevski, Gjore, Dumurđanov, Nikola, Pendić, Jugoslav, Blažeska, Zlata, Stefanović, Sofija. Early Neolithic tell of Vrbjanska Čuka in Pelagonia. Praehistorische Zeitschrift (in press).

Кузман, Паско. „Палеолит во Македонија“. Macedonia Acta Archaeologica 13 (1993), 13-18. Скопје.

Perlès, Catherine. The Distribution of Magoules in Eastern Thessaly. In Halstead, P. (ed.) Neolithic Society in Greece (1999), 42-56. Sheffield: Sheffield Academic Press.

Rosenstock, Eva. Tells in Südwestasien und Süosteuropa: Verbreitung, Entstehung und Definition eines Siedlungsphänomens. Urgeschichtliche Studien II: Grunbach, 2009.

Санев, Воислав. „Неолитско светилиште од Тумба во Маџари“. Macedonia Acta Archaeologica 9 (1988), 9-30. Скопје.

Санев, Воислав. Амзабегово: населба од раниот, средниот и доџниот неолит во Македонија, Штип: НУЗСК-Штип, 2009.

Симоска, Драгица и Санев, Воислав. „Неолитска населба Велушка тумба кај Битола“. Macedoniae Acta Archaeologica 1 (1975), 25-85. 
Симоска, Драгица и Санев, Воислав. Праисторија во Централна Пелагонија, Битола: Народен музеј Битола, 1976.

Симоска, Драгица; Китаноски, Благоја и Тодоровиќ, Јован. „Населбата Црнобуки и проблемот на истоимената култура во светлината на новите археолошки истражувања“. Macedonia Acta Archaeologica 2 (1976), 43-83. Прилеп.

Симоска, Драгица; Китаноски, Благоја и Тодоровиќ, Јован. „Неолитска населба во село Могила кај Битола“. Macedonia Acta Archaeologica 5 (1979), 9-30.

Симоска, Драгица и Кузман, Паско. „Тумба Оптичари“. Arheološki Pregled 1988 (1990), 63-66. Ljubljana.

Стојанова Канзурова, Елена. Архитектонски недвижни објекти од Тумба-Маџари. Macedoniae Acta Archaeologica 20 (2011), 35-52. Скопје.

Темелкоски, Душко. „Енеолитска населба Крушеанска Чука“. Macedonia Acta Archaeologica 15 (1999) 33-45.

Tolevski, Igor and Stančevski, Ivan Katlanovsko ezero-Blato i negovata okolina: kulturni impulsi od neolitskiot period. Vo Fidanoski, Lj. and Naumov, G. (ur.) Neolitot vo Makedonija II: čekor napred vo proučuvaweto na prvite zemjodelski opštestva (2018), 43-56. Skopje: Centar za istražuvanje na predistorijata.

Hofmann, R.; Moetz, F. K. and Müller, J. Tells: Social and Environmental Space. Bonn: Rudolf Habelt GMBH, 2012.

Chausidis, Nikos. Neolithic Ceramic Figurines in the Shape of a Woman-House from the Republic of Macedonia. In Gheorghiu, D. and Cyphers, A. (eds.), Anthropomorphic and Zoomorphic miniature figures in Eurasia, Africa and Meso-America: morphology, materiality, technology, function and context (2010), 25-35. Oxford: Archaeopress.

\section{GOCE NAUMOV}

Center for Prehistoric Research

Goce Delčev University, Štip

gocenaumov@gmail.com

\section{PELAGONIAN TELLS FROM PREHISTORY TO MIDDLE AGES (SUMMARY)}

The paper provides an explication on how the tells in Pelagonia appear, but also how they continue to function in Classical period and the Middle Ages. Therefore Vrbjanska Cuka site is given as a case study in order to elaborate the character of tells from prehistory to their medieval occupation. It is apparent that this tell is a complex site that contains a prehistoric settlement, Classical economic buildings and a medieval necropolis with many storage pits. At the very beginning, it is a settlement that has no pre-Neolithic development stages, but immediately, from the earliest stages, it is established as an defined economic center concentrated on agriculture as a primary branch. Although Vrbjanska Čhuka stands out from the other Pelagonian tells, especially in regard to architecture, still the other settlements of this kind have a similar formation process. None of the tells explored so far has an initial 
stage in which the settlement adapts to the environment and is gradually built into a stable Neolithic village. On the contrary, all a dozen Early Neolithic tells, excavated from the last to the first Neolithic layer, are immediately established as defined settlements with impressive material culture that is not the a result of social experimentation, but from the very beginning demonstrate extremely high technical and aesthetic qualities. This confirms that those who used these objects and lived in these settlements came as already determined communities with a very clear goal - discovering fertile soil and a rich source of resources.

Where these communities came from and how they came is a topic that cannot be discussed much at this time, although the similarities with the material culture and settlement concept present earlier in Thessaly and partly in Anatolia are apparent. The similarity in the early chronology of most of the Pelagonian tells again indicates that this process occurred relatively quickly in a certain period, i.e. around $6000 \mathrm{BC}$. This means that agricultural communities were looking for a specific space in which they could develop their own economic and existential goals, a process that probably followed the pioneering examination of the environment. It should be noted that on none of the tells in Pelagonia, at least so far no Mesolithic or Early Neolithic aceramic phase has been identified. Therefore, the so-called camps of the Neolithic "scouts" should be expected in other locations where the agricultural population was invited or attracted to inhabit the wetland valley area. This process may have been rapid, but it could also be gradual, so that Pelagonia in short but dense stages became attractive to more communities.

This is confirmed by the already established pattern of tells formation present in Thessaly and Anatolia, which was apparently repeated in Pelagonia. The first agricultural communities focused on the occupation of new areas, especially valleys filled with wetlands, around which there was an abundance of fertile soil. It was there that they established smaller settlements which were intensively renewed and stratified. Instead of expanding their villages, these communities built new buildings on the older ones, occupying a concrete smaller territory, but also establishing a strong continuous connection with their ancestors. So far, no intramural burial has been discovered on any of the Neolithic tells in Pelagonia, which would indicate this intergenerational symbolic connection. However, most of them abound in anthropomorphic house models, hybridized representations of anthropomorphic architecture, which were used as commemorative lamps. Probably in that way the respect for the ancestors was emphasized and the connection with them was ritually strengthened. In that sense, the tells are symbolic entities that not only have in their essence the agricultural economy, but also the connection between the generations that create them and continuously renew them.

In this context, Vrbjanska Čuka stands out as a sort of center in which technological investment has been made in the field of architecture. The massive houses and granaries, as well as the multitude of clay installations in their interior, emphasize the uniqueness of this settlement, but also of the population that lived in it. Not only did they build these fascinating structures, but they also had a remarkable material culture consisting of fine pottery, anthropomorphic house models, figurines, altars, and so on. These technical and aesthetic achievements are not only a result of the mental capacity and cognitive-manual abilities of the inhabitants of Vrbjanska Čuka, but also of the economic power they had in relation to the hitherto known Neolithic settlements in Pelagonia. It definitely stood out from the rest as an economic center that is based on the accumulation and processing of cereals. Surely, this economic act should not be understood only through the prism of the 
economy, because the massive and numerous clay installations (granaries and bins), for storage and processing of wheat and barley, were decorated with identical applied motifs as those of the small clay altars.

But the life of Vrbjanska Čuka and numerous other Neolithic tells does not end in the Neolithic, but on the contrary it continues. In the case of this site, there is a large temporal hiatus before it became active again in the Roman era and the Middle Ages, while several other tells, although intermittent, were followed by the Eneolithic and Bronze Age phases. The tells remained functional as settlements in prehistory, but their role changed in the Roman period and the Middle Ages. The position of these sites in the fertile Pelagonian fields allows them to be ancient centers that will coordinate and distribute grain throughout the Roman Empire, so that the facilities of the villa rustica type were built onto them. They retain a similar role in the Middle Ages, especially in regard to grain storage pits, but the tells will also be turned into necropolises where the surrounding population was probably buried. This sacral function further emphasized their symbolic character, especially in the relation between the grain and human life as an important thread that explains the continuity and rebirth. In this way, the tells, even after six millennia, play a similar role in strengthening the symbolic ties between living communities and their ancestors, despite the fact that they are completely different populations that lived in prehistory and the Middle Ages. 
